\title{
COMPARAÇÃO DE DIETAS ARTIFICIAIS PARA Heliothis wïnescers \\ (FABR., 1781) (LEPIDOPTERA: NOCTUIDAE) ATRAVÉS DE ESTUDOS BIOMÉTRICOS E NUTRICIONAIS
}

\section{IRINEU LOBO RODRIGUES FILHO}

\author{
Engenheiro Agrónomo
}

Orientador: Prof. Dr. JOSÉ ROBERTO POSTALI PARRA

Dissertação apresenta à Escola Superior de Agricultura "Luiz de Queiroz", da Uni versidade de São Paulo, para obtenção do do título de Mestre em Cièncias Biolögicas - Área de Concentração: Entomologia.

\author{
$\begin{array}{llllllllllllll}P & I & R & A & C & I & C & A & B & A\end{array}$ \\ Estado de São Paulo - Brasil \\ Setembro - 1989
}


Ficha catalográfica preparada pela Seção de Livros da Divisão de Biblioteca e Documentação - PCAP/USP

Rodrigues Filho, Irineu Lobo

R696c Comparação de dietas artificiais para Heliothis virescens (Fabr., 1781)(Lepidoptera: Noctuidae) através de estudos biométricos e nutricionais. Pi racicaba, 1989.

$86 p$. ilus.

Diss.(Mestre) - ESALQ

Bibliografia.

1. Algodão - Praga 2. Lagarta do algodão - Cres cimento 3. Lagarta do algodão - Dieta artificial 4. Lagarta do algodão - Nutrição I. Escola Superior de Agricultura Luiz de Queiroz, Piracicaba.

CDD 632.78 


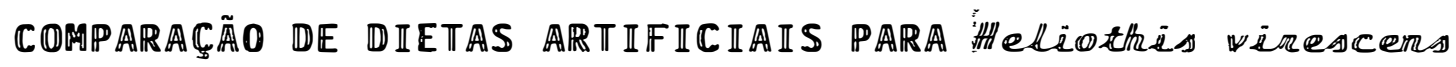
《FABR., TIBI》 (ULEPIDOPTERA: NOCTUIDAED ATRAVÉS DEE ESTUDOS BIOMEATRICOS E NOTTRICIONAIS

\section{IRINEU IOBO RODRIGUES FILHO}

Aprovada em: 18.09.1989

Comissão Julgadora:

Prof. Dr. José Roberto Postali Parra ESALQ/USP

Prof. Dr. José Djair Vendramim ESALQ/USP

Dr. Ervino Bleicher EMPACE/EMBRAPA

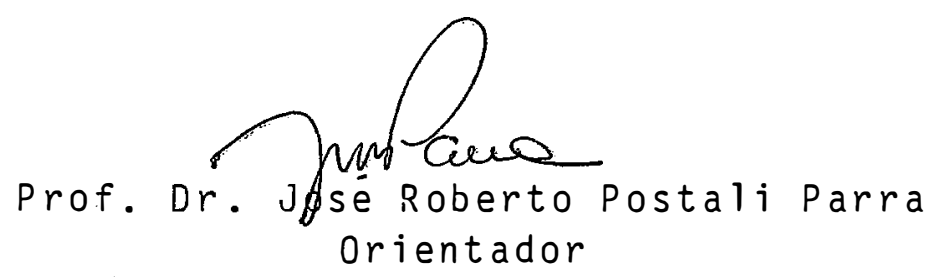


i i.

A todos os $\angle O B O$ RODRMGUES, especialmente a $\mathbb{U} \| \mathbb{C} \mathscr{T} \mathbb{H} \mathscr{A}$, minha avó, DEDJCO.

A minha esposa, IACQULUIME, e aos meus Rilhos $P$ AlllLAl e $\mathbb{F E L T P E}$, OFEREÇO. 
i i i.

\section{AGRADECIMENTOS}

Ao Dr. J.R.P. PARRA, da ESALQ/USP, pela valiosa orientação e indispensável apoio.

À CAPES e FINEP, pelos recursos materiais colocados à nossa disposição.

Aos Professores ELISA HELENA FARIA, FRANCISCO ADEMAR COSTA, da UFRRJ, e RICARDO B. SGRILLO, do CENA-USP, pelas anälises e apoio estatístico:

Ao Professor GONZALO E. MOYA BORJA, da UFRRJ, pe 1 a redação do "Summary".

A todos aqueles que de qualquer forma e sob qualquer pretexto, tenham influenciado na realização deste tra balho e especialmente em mim. 
iv.

\section{SUMĂR IO}

Pāgina

LISTA DE FIGURAS $\ldots \ldots \ldots \ldots \ldots \ldots \ldots \ldots \ldots \ldots \ldots \ldots \ldots \ldots \ldots \ldots$ vi.

LISTA DE TABELAS ..................... viii.

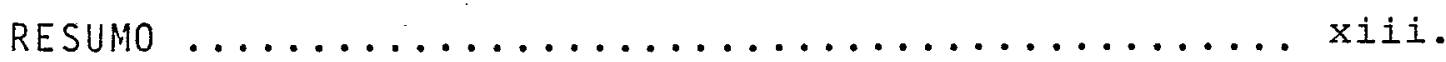

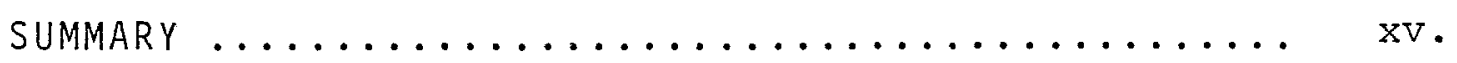

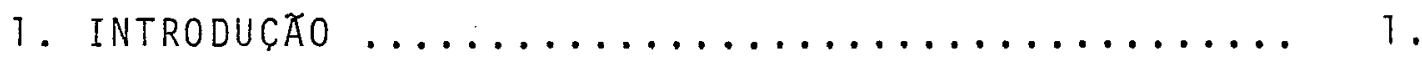

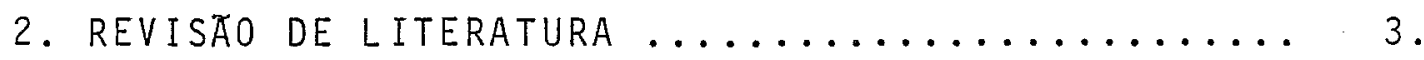

2.1. Dietas artificiais para Heliothis virescens

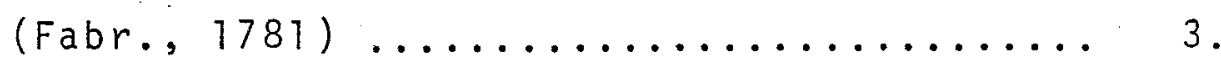

2.2. Dados biológicos de H. virescens em dietas natural e artificial ............... 4 .

2.2.1. Fase de ovo .............. 4 .

2.2.2. Fase de larva $\ldots \ldots \ldots \ldots \ldots \ldots \ldots 6.6$.

2.2.3. Fase de pupa ............... 8 .

2.2.4. Fase de adulto .............. 9 .

2.3. Nutrição de $H$. virescens - consumo e utilização de a 1 imento .................. 12 .

2.4. Anormalidades morfológicas como critério de avaliaça para estudos de insetos em meios artificiais .................... 16 .

2.5. Controle de qualidade em geracões sucessivas ..................... 19 ,

3. MATERIAL E METOdOS ..................... 21 .

3.1. Parāmetros biológicos estudados ......... 22.

3.1 .1 . Fase de larva $\ldots \ldots \ldots \ldots \ldots \ldots .22$. 
Pāgina

3.1.2. Fase de pupa ................ 23 .

3.1.3. Fase de aduito ............... 23 .

3.1.4. Fase de ovo ............... 24 .

3.2. Indices nutricionais ............. 25 .

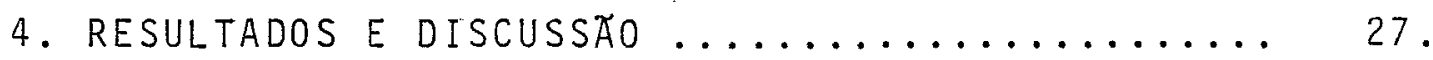

4.1. Fase de Tarva .................... 27 .

4.1.1. Dietas à base de soja-germe de trigo ("SGT") e feijão-levedura ("FL") 28 .

4.7.2. Dietas à base de milho-germe de tri go-levedura ("MGTL") e caseina-germe de trigo ("CGT") .............. 32 .

4.2. Fase de pupa ................... 34 .

4.3. Fase de adulto................. 43 .

4.4. Fase de ovo ................... 46 .

4.5. Consumo e utilização das dietas "MGTL" e "CGT" por lagartas de H. virescens ...... 47.

4.6. Considerações gerais .............. 49.

5. CONCLUSOES ......................... 52 .

REFERENCIAS BIBLIOGRAFICAS ............... 53 .

APENDICES $\ldots \ldots \ldots \ldots \ldots \ldots \ldots \ldots \ldots \ldots \ldots \ldots \ldots \ldots \ldots \ldots \ldots$ 


\section{LISTA DE FIGURAS}

Pägs.

FIGURA 1. Percentual de lagartas de H. virescens, mantidas em duas dietas artificiais, que completaram a fase larval e respectivas durações. Temperatura de $24 \pm 6{ }^{\circ} \mathrm{C}, \quad$ UR de $70 \pm 10 \%$ e fotofase de 14 horas ... 67 .

FIGURA 2. Percentual de deformações morfolögicas de pupas de $H$. virescens obtidas em die tas à base de farinha de milho - germe de trigo - levedura de cerveja ("MGTL"), caseina - germe de trigo ("CGT"), em ge rações sucessivas, em comparação aos da dos obtidos por MORETI e PARRA (1983).

68 .

FIGURA 3. Parāmetros reprodutivos, perĩodo de incubação e viabilidade de ovos de $H$. virescens, criada em duas dietas artificiais. Temperaturá de $24 \pm 6{ }^{\circ} \mathrm{C}$, UR de $70 \pm 10 \%$ e fotofase de 14 horas ...... 69.

FIGURA 4. Percentual de fëmeas de H. virescens pro venientes de duas dietas artificiais, 
vii.

Pāgs.

que realizaram posturas em cinco gerações sucessivas. Temperatura de $24 \pm$

$6^{\circ} \mathrm{C}$, UR de $70 \pm 10 \%$ e fotofase de 14 ho

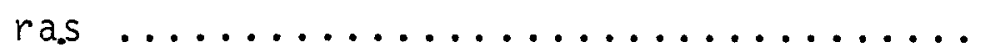

70.

FIGURA 5. Percentual de fëmeas de H. virescens pro venientes de duas dietas artificiais, que realizaram posturas inviāveis em cinco geracões sucessivas. Temperatura de $24 \pm 6{ }^{\circ} \mathrm{C}$, UR de $70 \pm 10 \%$ e fotofa se de 14 horas ................. 71 . 


\section{LISTA DE TABELAS}

Pāgs.

TABELA 1. Composição de dietas artificiais, utilizadas para criacão de $H$. virescens ........ 72 .

TABELA 2. Duração da fase larval (1agarta + prē-pupa) de H. virescens mantida em dietas artificiais à base de farinha de soja - germe de trigo ("SGT"), feijão - levedura de cerveja ("FL"), farinha de milho - germe de trigo - levedura ("MGTL") e caseīna - germe de trigo ("CGT"), por gerações sucessivas. Tem peratura de $24 \pm 6{ }^{\circ} \mathrm{C}$, UR de $70 \pm 10 \%$ e foto

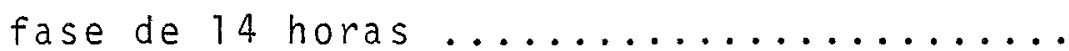

TABELA 3. Duração e viabilidade da fase larval de $H$. virescens, obtidas por diferentes autores em criacões mantidas em dietas artificiais. 74 .

TABELA 4. Mortalidade e viabilidade total, observadas na fase larval (lagarta + prē-pupa) de $H$. virescens, mantida em dietas artificiais $\bar{a}$ base de farinha de milho - germe de trigo levedura de cerveja ("MGTL") e caseĩna - 
germe de trigo ("CGT"), por geracōes sucessivas. Temperatura de $24 \pm 6{ }^{\circ} \mathrm{C}$, UR de $70 \pm$ $10 \%$ e fotofase de 74 horas ........... 75 .

TABELA 5. Duraç̃o da fase, proporcão e razão sexual de pupas de H. virescens, provenientes de lagartas mantidas em dietas artificiais, $\bar{a}$ ba se de farinha de milho - germe de trigo levedura de cerveja ("MGTL") e caseina-ger me de trigo ("CGT"), por geracões sucessivas. Temperatura de $24 \pm 6{ }^{\circ} \mathrm{C}$, UR de $70 \pm 10 \%$ e fotofase de 14 horas ................. 76 .

TABELA 6. Peso de pupas de H. virescens, provenientes de lagartas mantidas em dietas artificiais, à base de farinha de milho - germe de trigo - Tevedura de cerveja ("MGTL") e caseína - germe de trigo ("CGT"), por gerações sucessivas. Temperatura de $24 \pm 6^{\circ} \mathrm{C}$, UR de $70 \pm 10 \%$ e fotofase de 14 horas .......... 77 .

TABELA 7. Duração da fase, peso e viabilidade de pupas de H. virescens, obtidas por diferentes autores em criacões mantidas em dietas ar-

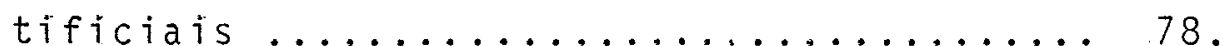

TABELA 8. Mortalidade e viabilidade total, observadas 
pāgs.

na fase de pupa de H. virescens, mantida em dietas artificiais ā base de farinha de milho - germe de trïgo - levedura de cerveja ("MGTL") e caseīna - germe de tri go ("CGT"), por geracões sucessivas. Tem peratura de $24 \pm 6^{\circ} \mathrm{C}$, UR de $70 \pm 10 \%$ e fotofase de 14 horas .............. 79 .

TABELA 9. Parāmetros reprodutivos dos adultos de H. virescens, alimentados com solução de mel a $10 \%$, provenientes de lagartas em dietas artificiais, à base de farinha de milho - germe de trigo - levedura de cer veja ("MGTL") e caseina - germe de trigo ("CGT"), por gerações sucessivas. Tem peratura de $24 \pm 6^{\circ} \mathrm{C}$, UR de $70 \pm 10 \%$ e

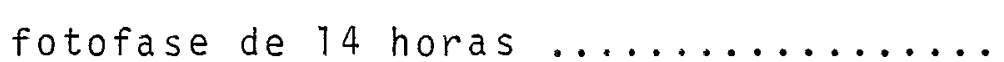

80.

TABELA 10. Longevidade e parāmetros reprodutivos de H. virescens, obtidos por diferentes autores em criacões mantidas em dietas artificiais $\ldots \ldots \ldots \ldots \ldots \ldots \ldots \ldots$

81

TABELA 11: Longevidade dos adultos de H, virescens, alimentados com solução de mel a $10 \%$, pro venientes de lagartas mantidas em dietas 
artificiais, à base de farinha de milho germe de trigo - 1evedura de cerveja ("MGTL") e caseina - germe de trigo ("CGT") por geracões sucessivas. Temperatura de $24 \pm 6{ }^{\circ} \mathrm{C}$, UR de $70 \pm 10 \%$ e fotofase de 14 horas...

TABELA 12. Período de incubação e viabilidade dos ovos produzidos por adultos de $H$. virescens, alimentados com solução de mel a $10 \%$, provenientes de lagartas mantidas em dietas artificiais à base de farinha de mi1ho - germe de trigo - levedura de cerveja ("MGTL") e caseina - germe de trigo ("CGT") por geracões sucessivas. Temperatu ra de $24 \pm 6{ }^{\circ} \mathrm{C}$, UR de $70 \pm 10 \%$ e fotofase de 14 horas ...................... 83 .

TABELA 13. Perĩodo de incubação e viabilidade de ovos de H. virescens, obtidos por diferentes a tores em criacões mantidas em dietas arti-

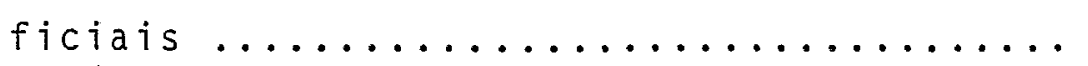

TABELA 14. Consumo e utilizacão de alimentos por lagartas de H. virescens, no māximo desenvol vimento da geracão $F_{2}$, mantidas em dietas artificiais à base de farinha de milho - 
xii.

Pàgs.

germe de trigo - levedura de cerveja ("MGTL")

e caseina - germe de trigo ("CGT"). Tempe-

ratura de $24 \pm 6^{\circ} \mathrm{C}$, UR de $70 \pm 10 \%$ e foto-

fase de 14 horas .................. 85 .

TABELA 15. Indices nutricionais alcancados por lagartas de $H$. virescens, no mäximo desenvolvimento da geração $F_{2}$, mantidas em dietas artificiais à base de farinha de milho germe de trígo - levedura de cerveja ("MGTL") e caseĩna - germe de trigo ("CGT"). Temperatura de $24 \pm 6^{\circ} \mathrm{C}$, UR de $70 \pm 10 \%$ e fotofase de 14 horas .................. 86 . 


\title{
COMPARACAO DE DIETAS ARTIFICIAIS PARA Heliothis virescens (FABR., 1781) (LEPIDOPTERA： NOCTUIDAE) ATRAVES DE ESTUDOS BIOMETRICOS E NUTRICIONAIS
}

\author{
Autor: IRINEU LOBO RODRIGUES FILHO \\ Orientador: Prof. Dr. JOSE ROBERTO POSTALI PARRA
}

\section{RESUMO}

Com o objetivo de substituir nas criacões de H. virescens, a dieta padrão à base de caseīna-germe de trị go, por outra(s) com menor custo ecorōmico e componentes de fācil aquisição no mercado brasileiro, foram comparadas as dietas à base de: farinha de soja-germe de trigo ("SGT"), feijão cozido - levedura de cerveja ("FL"), farinha de mi1ho - germe de trigo - levedura de cerveja ("MGTL") e caseina - germe de trigo ("CGT").

os experimentos foram conduzidos à temperatura de $24 \pm 6^{\circ} \mathrm{C}$, umidade relativa de $70 \pm 10 \%$ e fotofase de 14 horas, sendo avaliados, na segunda geracão, os indices nutricionaís $A D$ (Digestibilidade Aproximada), ECI (Eficiência de Conversão do Ingerido), ECD (Eficiēncia de Conversão do Digerido) e custo metabólico (100 - ECD) e em todas as geracões produzidas, os seguintes parâmetros biológicos: du 
ração e viabilidade das fases de ovo, lagarta e pupa; duração da fase de adulto; peso, razão sexual e aberrações, na fase de pupa; perīodos de prē-oviposicão e postura; nū mero de ovos/fēmea.

Paralelamente, foram discutidos os principais fatores que afetaram a viabilidade das respectivas fases, sendo descritas anomalias e aberracões ocorridas em lagartas e pupas.

Os tratamentos "SGT" e "FL" apresentaram as maiores durações e as mais baixas viabilidades da fase larval, determinando assim, a interrupcão biológica das criacões na primeira e segunda geração, respectivamente.

Os tratamentos "MGTL" e "CGT" propiciaram estudos por 5 geracões sucessivas, tendo o primeiro, alēm do custo económico baixo, apresentado características nutricionais desejäveis para o consumo e utilizacão de uma dieta, bem como proporcionado a melhor performance biológica do inseto, em todas as gerações.

os resultados obtidos permitem concluir que a dieta composta de farinha de milho, germe-de-trigo e le vedura de cerveja, pode substituir a dieta convencional $\bar{a}$ base de caseína e germe-de-trigo, em criacões de H. virescens nas condições brasileiras. 


\section{COMPARISON OF ARTIFICIAL DIETS FOR REARING Hellíthis

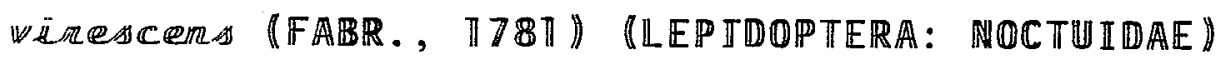 \\ USING BIOMETRIC AND NUTRIIIIONAL STUDIES}

Author: IRINEU LOBO RODRIGUES FILHO

Adviser: Prof. Dr. JOSË ROBERTO POSTALI PARRA

\section{SUMMARY}

The association of the casein and wheat germ. have been commonly used in artificial diets for rearing $H$. vinescens. To substitute these ingredients for other ones which are cheaper and easier to get in brazilian markets, diets based on soybean - wheat germ ("SGT"), boiled beanyeast ("FL"), corn meal - wheat germ - yeast ("MGTL"), and casein - wheat germ ("CGT") were tested.

The experiments were carried out at the temperature of $24 \pm 6{ }^{\circ} \mathrm{C}$, relative humidity $70 \pm 10 \%$ and 14 hour photophase. The nutritional indeces AD, ECI, ECD (Aproximate Digestibility; Efficiency of Conversion of Ingested Food and Efficiency of Conversion of Digested Food, respectively) and metabolic cost (100-E.C.D.) were only evaluated in the second generation. The following biological parameters were studied: duration and viability of the egg, larval and pupal stages; duration of the adult stage; pupal weight, sexual rate, pupal aberrations; preoviposition and oviposition periods and number of eggs 
$x \vee i$.

per female, were studied.

Simultaneously, the effect of the main factors on viability of different stages of lyfe cycle, as well on the mal formations observed in larvae and pupae were discussed.

Longer periods and lower viabilities of the larval stage were observed in diets "SGT" and "FL" determining biological interruptions of the first and second generations, respectively.

$$
\text { Diets "MGTL" and "CGT"allow to rear } H \text {. }
$$

vinescens for five generations. However, diet "MGTL" was the cheapest, well acepted by the insect and the biological performance in all generations was considered excellent.

In conclusion, a diet based on corn mealwheat germ - yeast can substitutes the conventional diet based on casein wheat germ for rearing $H$. vinescens under brazilian conditions. 


\section{IATRODUCAO}

A utilizacāo de colōnias de insetos de laboratōrio é de fundamental importāncia para a Entomologia pu ra ou aplicada. Em relação aos estudos de insetos pragas, a relevância da manutenção de criacões em laboratōrio tor na-se ōbvia desde que, para a integracão dos diversos métodos de controle, visando ao manejo de pragas, hā necessi dade de se dispor de grande quantidade de insetos. Para suprir esta necessidade crescente, houve nas ūltimas décadas uma grande evolucäo no desenvolvimento de meios artificiais em substituicão aos naturais, existindo atualmente um grande nümero de dietas para espécies de diferentes Ordens e Familias (SINGH, 1977; SINGH e MOORE, 1985), tornando possivel independer do hospedeiro natural e dispor de insetos durante todo o ano.

A Entomologia brasileira ainda carece de estudos bāsicos para diversas pragas de importāncia agríico1 a como Heliothis virescens (Fabr., 1781), que a partir de 1957 aumentou a sua importāncia para a cultura algodoeira, tornando-se, então, um dos insetos mais prejudiciais

a cotonicultura pelo seu ataque aos örgãos de frutificaça 
(BLEICHER, 1982 ).

Com o avanco das pesquisas sobre manejo de pragas do algodoeiro, torna-se necessārio o desenvolvimento de tēcnicas que possam manter à disposicão do pesquisador populacões em laboratōrio desse inseto, principalmente nos periodos de entressafra, para que sejam esclarecidos aspectos básicos da mesma. Assim, hā necessidade do desenvolvimento de meios artificiais, que sejam porém, compatíveis com a realidade nacional.

o presente trabalho teve por objetivo avaTiar quatro meios artificiais para a criacão de H. virescens, atravēs do seu desenvolvimento biolōgico e aspectos nutricionais dos meios. Levou-se tambëm em consideraçăo, a disponibilidade, facilidade de aquisicão e manipulação dos componentes das dietas, bem como, a adaptação, comportamen to e qualidade do inseto por geracões sucessivas, visando, assim, criar possibilidades de manutencão constante do inseto em laboratōrio, com caracterīsticas semelhantes aos insetos da natureza. 


\section{REVISÃO DE LITERATURA}

\subsection{Dietas artificiais para Heliothis virescens (Fabr., $1781)$}

Os trabalhos com dietas para Heliothis spp., podem ser agrupados em 2 fases, a primeira delas compreendendo pesquisas para o estabelecimento das exigencicias nutri cionais do inseto e a segunda, engrobando a redução dos cus tos destas dietas.

RAULSTON e KING (1984) revisaram o assunto, concluindo que, de maneira geral, as colónias de pesquisas são mantidas na dieta original à base de caseina-germe de trigo, desenvolvida por VANDERZANT et alii (1962) e que para as criacões em larga escala, devido aos altos custos, torna-se necessārio o desenvolvimento de novas dietas ou mo dificacões das jă existentes. Assim, as dietas artificiais atualmente utilizadas para $H$. virescens, tèm por base aquelas desenvolvidas por VANDERZANT et alii (1962) para Heliothis zea (BOd., 1850) e por SHOREY (1963), para Trichoplusia ni (Hueb., 1802). A primeira dieta tem como fonte protéica a associacão de caseina e germe de trigo, tendo sido modificada por BERGER (1963), constituindo-se, então, em um 
padrão na maioria das criacões de H. virescens. Buscando diminuir os custos dessa formulação, RAULSTON e SHAVER (1970) reduziram a quantidade de àgua, adicionando sabugo de milho moído à dieta e SHAVER e RAULSTON (1971) substituĩram a caseina na dieta original por farinhas de soja, sendo a possibilidade de reducão quantitativa e quali tativa do suplemento vitaminico, nessas novas formulacões, estudada por RAULSTON (1975).

A fonte protéica da segunda dieta (SHOREY, 1963) foi feijão-de-lima associado à levedura de cerveja, sendo modificada por SHOREY e HALE (1965) que substituiram a variedade de feijão, eliminando ācido sōrbico e for maldeĩdo da formulação e por PATANA (1969), que tambëm trocou a variedade de feijäo da dieta inicial.

\subsection{Dados biológicos de $H$. virescens em dietas natu- ral e artificial}

\subsubsection{Fase de ovo}

O periodo de incubação de $H$. virescens è va riável em dietas naturai ou artificial, de 2 a 5 dias, apresentando uma mēdia ao redor dos 3 dias (HERRICK, 1925; FONSECA, 1945; GARCIA, 1960; METCALF et alij, 1962; HABIB e PATEL, 1977; MORETI e PARRA, 1983; PRECETTI, 1984; CORREIA e VENORAMIM, 1986), podendo variar drasticamente por 
apresentar uma correlação inversa com a temperatura (ENKERLIN e LASTRA, 1967/1968; BUTLER e HAMILTON, 1976; BUTLER et alii, 1979; SOUZA, 1981). Por outro 1ado, MORETI e PARRA (1983) verificaram que à temperatura constante de $25^{\circ} \mathrm{C}$, realmente manteve aquele periodo em 3 dias, independente do tipo da dieta (natural ou artificial) e do nū mero de geracões, o que corroborou com os dados obtidos por SOUZA (1981).

A viabilidade de ovos de H. virescens $\bar{e} e x-$ tremamente variāvel. Assim, segundo NADGAUDA e PITRE (1983), este parāmetro não sofreu influēncia da dieta lar val, sendo que MORETI e PARRA (1983) observaram uma maior viabilidade em dieta artificial, com influencia da geracão de laboratório neste percentual. PRECETTI (1984) e COR REIA e VENDRAMIM (1986) tambēm encontraram diferenças sig nificativas da viabilidade em diferentes cultivares de al godoeiro. A elevação da temperatura influi diretamente na redução da fecundidade e fertilidade dos ovos (FYE e POOLE, 1971; SOUZA, 1981), obtendo-se maiores viabilidades nas temperaturas em torno dos $25^{\circ} \mathrm{C}$ (Tollefson $e$ watson ${ }^{3}$ citados por NADGAUDA e PITRE, 1983). Segundo GUERRA e OUYE

I TOLLEFSON, M.S. I WATSON, T.F. Sazonal effects on the biology and damage by tobacco budworm in cotton. Environmental Entomology. College Park, 74:714-717, 1981 . 
(1968), a exposicão contínua dos ovos a temperaturas elevadas $\left(46,7^{\circ} \mathrm{C}\right)$ foi letal ao desenvolvimento embrionārio, - que não ocorreu em temperaturas de $43,4{ }^{\circ} \mathrm{C}$. JONES et alii (1978) observaram a influēncia negativa no desenvolvimenembrionārio de temperaturas constantes com baixa umidade relativa do ar. Por outro lado, FYE e SURBER (1971) verifí cando a influência conjunta daqueles dois fatores, observa ram uma redução drāstica da viabilidade em temperaturas de $35-40^{\circ} \mathrm{C}$ e umidades relativas de $10-20 \%, 40$ e $60 \%$, verificando, ainda, alta mortalidade de lagartas de um dia, provenientes de ovos expostos a $35^{\circ} \mathrm{C}$ por 8,10 e 16 horas ou a $40^{\circ} \mathrm{C}$ por 4 horas, em umidades relativas de $10-20 \%$.

\subsubsection{Fase de larva}

0 nūmero de ĩnstares deste inseto é variāve $1^{-}$de 5 a 7 , aumentando a cada geração o número de lagartas que apre sentam um maior nümero de instares (MORETI e PARRA, 1983; NADGAUDA e PITRE, 1983). A duração desses instares foi de 2,4 dias para o primeiro e segundo; 2,8 dias para o tereiro e quarto; 4,6 dias para o quinto e 6,4 dias para o sexto instar, com medidas de cāpsulas cefälicas variando de $0,26-0,31 \mathrm{~mm} ; 0,43-0,52 \mathrm{~mm} ; 0,68-0,95 \mathrm{~mm} ; 1,42-$ $-1,64 \mathrm{~mm}$, respectivamente, para o $10,20,30$ e 40 instares e 2,30$-2,61 \mathrm{~mm}$ para 050 e 60 instares (BOLDT et a $1 \mathrm{i} i, 1975$ ).

A duracão da fase larval sofre influência do substrato alimentar. Assim, em dieta natural, a duração foi 
menor em frutos do quiabeiro quando comparadas à criaçăo em folhas de algodoeiro (HABIB e PATEL, 1977), sendo que nesta ūitima existiu a influéncia de diferentes cul tivares (PRECETTI, 1984; CORREIA e VENDRAMIM, 1986) e de gerações sucessivas, acarretando um aumento na duração média a cada geração (MORETI \& PARRA, 1983). Entretanto as criações em dietas artificiais proporcionaram uma du ração mëdia menor da fase larval, em comparação com as dietas naturais; cerca de 12 a 23 e 14,4 a 31 dias, respectivamente (MORGAN e MCDONOUGH, 1917; SZUMKOWSKI, 1954; KINCADE et a1ii, 1967; SOUZA, 1981; MORETI e PARRA, 1983). Nos estudos de interações temperaturas e dietas, os valores mais baixos de duraça da fase larval em todas as condições térmicas pesquisadas, foram encontrados em dietas artificiais, sendo inversamente cor relacionados com a temperatura (GUERRA, 1970; BUTLER et a 1ii, 1976; MONTEWKA et alii, 1976; BUTLER et alii, 1979; SOUZA, 1981; NADGAUDA E PITRE, 1983).

A luz tambēm influi no desenvolvimento la val (SULLIVAN et alij, 1969) sendo a condicão de 1.4 horas de fotofase normalmente utilizada em criacões de $H$. virescens (SOUZA, 1981; MORETI e PARRA, 1983 e PRECETTI, $1984)$.

A viabilidade desta fase varia com o subs trato, nümero de geracões, temperatura e condicões de sa nidade da criação (SHOREY e HALE, 1965; SHAVER e LUKE- 
FAHR, 1969; GUERRA e BHUYA, 1977; NADGAUDA e PITRE, 1983). Em dieta natural, a viabilidade decresceu a cada geracão, enquanto que, em dieta artificial, existiu um decréscimo nas 3 primeiras gerações, aumentando a partir desse ponto e assim manten-do-se constante atē a oitava geração. De maneira geral, as mais baixas viabilidades foram observadas no primeiro tipo de dieta em temperaturas de 25 a $30^{\circ} \mathrm{C}$ (SOU ZA, 1981 ; MORETI E PARRA, 1983).

\subsubsection{Fase de pupa}

Em dieta natural (folhas de algodoeiro), es ta fase variou de 10 a 27 dias tanto no campo como em $1 \underline{a}$ boratōrio (MORGAN e MCDONOUGH, 1917; HERRICK, 1925; SZUMKOWSKI, 1954; GARCIA, 1960; PRECETTI, 1984; CORREIA E VEN DRAMIM, 1986). De maneira geral, o período de pupa foi menor em dieta artificial do que dieta natural, aumentando,po rèm, a cada geração, com a maior duração sendo apresentada pelas pupas que dariam machos (MORETI e PARRA, 1983). Segundo NADGAUDA e PITRE (1983), a dieta larval apresentou pouca influência no período pupal, no entanto, PRECETTI (1984) e CORREIA e VENDRAMIM, 1986) observaran que diferentes cultivares de algodoeiro afetaram este parámetro.

Existe uma correlação inversa entre temperatura e duração da fase pupal, tanto em dieta natural como em dieta artificial, porem com intervalos maiores para es- 
ta ültima (SoUZA, 1981). Em contrapartida, exposições de pú pas às temperaturas de 35 a $40^{\circ} \mathrm{C}$ por 16 e 18 horas, respectivamente, provocaram baixas fecundidade e longevidade nos adultos resultantes (FYE e POOLE, 1971).

0 peso de pupas apresentou uma correlação dire ta com a temperatura, para lagartas alimentadas com soja e uma correlação inversa, para aquelas alimentadas com foThas de algodoeiro e dieta artificial à base de germe de trigo (SOUZA, 1981; NADGAUDA e PITRE, 1983). Entretanto, em média, o peso de pupas foi maior em'dieta artificiale(SHOREY e BHUYA, 1977; MORETI e PARRA, 1983). Em dieta natura1,COR REIA e VENDRAMIM (1986) registraram diferenças significati vas do peso de pupas, obtidas entre vários cultivares de algodoeiro, verificando, porém, a não existência de dife renças, entre sexos, dentro de uma mesma cultivar.

A viabilidade desta fase foi diretamente in fluenciada pela dieta larval, sendo maior em dieta artificial (MORETI e PARRA, 1983) e mais baixa nas temperaturas de 20 e $35^{\circ} \mathrm{C}$ (SOUZA, 1981 ).

\subsubsection{Fase de adumti}

A razão sexual a partir de criações em folthas de algodoeiro, foi 0,5 (HABIB e PATEL, 1977), no entanto ocorreram variações em função do tipo da dieta larval e do nümero de gerações (MORETI e PARRA, 1983).

Geralmente assume-se que igual nümero de ambos os sexos é produzido para continuação da espécie, podendo uma dieta ser caracterizada como pobre, se o número de machos exceder ao nümero de fémeas. Assim, em uma dieta ade 
quada, a proporção sexual esperada seria de $1: 1$, ou um nūmero de fëmeas pouco maior que o de machos (BHATTACHARYA e PANT, 1976). Entretanto não só a dieta larval influi na razão sexual como também a temperatura, pois a condicão térmica de $30^{\circ} \mathrm{C}$ gerou um maior nūmero de machos de $H$. virescens, independente do tipo da dieta (SOUZA, 1981).

A longevidade dos adultos foi afetada pela dieta larval quando comparadas duas dietas naturais (foThas de algodoeiro e frutos de quiabeiro) (HABIB e PATEL, 1977), não o sendo, por diferentes cultivares de algodoeiro (PRECETTI, 1984). No entanto, NADGAUDA e PITRE (1983) a firmaram que a dieta larval não afetou aquele parāmetro e MORETI e PARRA (1983) obtiveram uma diferenca significati va entre as longevidades de adultos, provenientes de lagar tas criadas em dieta natural e artificial, alcançando nesta ültima, os valores mais baixos.

Segundo SOUZA (1981), a Tongevidade apresentou uma correlacão inversa com a temperatura, fato este corroborado por NADGAUDA e PITRE (1983). A alimentação de adultos também influi na longevidade, sendo que os adultos alimentados por solução de sacarose, viveram em média, cerca de 2,3 vezes mais que os não alimentados e as fēmeas apresentaram a maior longevidade em ambas as situacões. MORETI e PARRA (1983) observaram em adultos al imentados com solução de mel a 10\%, uma longevidade média maior para aqueles oriundos de lagartas mantidas em 
dieta natural à base de folhas de algodoeiro.

o periodo de pré-oviposição foi menor em dietas naturais (GARCIA, 1960; MORETI e PARRA, 1983). No entanto, segundo NADGAUDA e PITRE (1983), dietas larvais ou temperaturas na faixa dos $20-30^{\circ} \mathrm{C}$, não influenciaram sig nificativamente este periodo. Por outro lado, BUTLER et alij (1979) e SOUZA (1981), observaram uma relação inversa entre a temperatura e o período de prē-oviposição.

A capacidade de postura foi afetada pela alimentação dos adultos, sendo que os alimentados ovipositaram cerca de 8,7 vezes mais que os não alimentados, apresen tando ainda, uma fertilidade 3 vezes superior (LUKEFAHR e MARTIN, 1964). A dieta larval pareceu, tambëm, influénciar naquela capacidade, sendo 1,44 vezes maior em adultos oriundos de lagartas criadas em folhas de algodoeiro,em com paração àquelas criadas em frutos de quiabeiro(HABIB e PATEL, 1977). Variação semelhante foi notada por MORETI e PAR RA(1983), comparando dietas natural e artificial, tendo sido $80 \%$ dos ovos, colocados até o quinto e sexto dias de pos tura. CORREIA E VENDAMIM(1986), avaliando a influência de diferentes cultivares de algodoeiro, encontraram diferen ças significativas no nümero médio de ovos por fémeas. Geralmente, o nümero de ovos por fèmea foi sempre maior em dieta artificiallGUERRA, 1970; GUERRA e BHUYA, 1977; HABIB e PATEL, 1977;MORETI e PARRA,1983), alcançado os valores mais altos em temperaturas de $20^{\circ} \mathrm{C}$ (NADGAUDA e PITRE, 1983). Entretanto, SOUZA (1981) concluiu que não houve influència da dieta ou temperatura na capacidade de postura de H. virescens. Segundo RAULSTON (1975), a origem da popu- 
lação inicial pode afetar a manutenção da sua base gené tica, e as variações no comportamento reprodutivo de $H$. vinescens, em laboratório, são geneticamente controladas, existindo maior influencia materna.

\subsection{Nutrição de $H$, virescens - consumo e utilizaçăo de al imento}

Segundo PARRA (1980), as publicacões de vārios autores demonstraram que a busca do conhecimento da nutricão qualitativa de insetos, em dietas naturais, receberam atenção desde o inīcio do sēculo. Porēm, somente nas ültimas décadas ocorreu o desenvolvimento de dietas artificiais, sendo a primeira tentativa de criacão de um inseto fitōfago realizada por BOTGER (1942) com Ostrinia nubilalis Hubner). Esse desenvolvimento e producão acentuaram-se nos ūttimos anos, para suprir as necessidades dos programas de pesquisas que exigiam grandes quantidades (criacões massais) de insetos. Face a isto, as exigenncias nutricionais qualitativas foram totalmente definidas, sendo semelhantes para a maioria dos insetos, enquanto que as exigencias quantitativas, devido em parte às dificuldades para se medir o consumo e a utilizacão de alimentos, não o foram (WALDBAUER, 1972).

Segundo KOGAN e PARRA.(1981), tal campo de estudos situa-se no limite da fisiologia alimentar e com- 
portamento de selecão do hospedeiro, sendo pois, necessārio à compreensão da adaptação de diferentes espécies de insetos a um dado hospedeiro, ou de determinada espécie a vārios hospedeiros. Dethier ${ }^{1}$,. citado por KOGAN e COPE (1974), sugeriu que a adaptação a um hospedeiro esta ria submetida a niveis sensoriais e a nîveis de utilizacão de alimentos. A seleção do hospedeiro ao nĩvel sensorial seria realizada por estímulos da planta, os quais in duziriam, ou năo, a orientaçăo, estabelecimento e manuten cão da alimentação (DETHIER et a 1 ij, 1960; BECK, 1965; KO GAN, 1975).

No que diz respeito à utilizacão do alimento, mesmo que qualitativamente as exigëncias nutricionais sejam uniformes, FRAENKEL (1959) afirmou que a seleção do hospedeiro é feita por substāncias secundārias (aleloquímicos), cuja interação com nutrientes tem sido determinada atravēs de indices nutricionais (REESE, 1977).

A grande maioria desses indices foram deter minados com insetos mantidos em dietas naturais, porém as medidas não eram padronizadas e os métodos variavam em precisão. WALDBAUER (1968) revisou o assunto, padronizando os indices para medir o consumo e utilização de alimen

1 DETHIER, V.G. Chemical insect attractants and repellents. Philadelphia, Blakiston Co., 1947, 289 p. 
tos por insetos fitōfagos. Recentemente foi apresentada uma nova contribuiçăo sobre o assunto por SLANSKY . e SCRIBER (1982), SLANSKY E RODRIGUES(1987) e KOGAN (1986).

SANG (1959) sugeriu que para uma mesma espécie deva existir mais de uma dieta adequada. KLEIN e KOGAN (1974) assinalaram a importáncia da determinacão da eficiēn cia de utilizacão do alimento na anălise da interação inseto-planta, e segundo BHATTACHARYA e PANT (1976), o desenvol vimento e crescimento de populacöes de insetos, dependem so bretudo da digestibilidade e da eficiencia de conversão do al imento em biomassa. Baseando-se nestes principios, os indices nutricionais têm sido utilizados para estudar a influéncia de substäncias especificas e o efeito de parasitói des em lagartas de H.virescens bem como, na seleção de dietas artificiais e na escolha de recipientes de criacão para aquele inseto. Assim, SHAVER et alii (1970) observaram que dietas contendo gossipol, não apresentaram efeitos na sua utilização por lagartas de H. virescens, embora o peso larval tenha diminuido e o consumo das dietas apresentado uma correlação inversa com a quantidade daquela substância. CHOU et alii (1973) encontraram uma significativa diferenca na digestibilidade aproximada das lagartas, mantidas em dietas químicamente definidas contendo dois isōmeros de metionina. DIKEMAN et alii (1981) demonstraram que as lagartas de $H$. virescens absorveram durante a digestäo, äcidos graxos po1 i-insaturados (1inoleico e linolênico). 
GUILLOT e VINSON (1973) constataram a redução do consumo de alimento em lagartas de H. Virescens, parasi tadas por Cardiochiles nigriceps, enquanto que BREWER e KING (1980) relataram que as lagartas de 30 ou 40 instares, parasitadas por Eucelatoria sp., consumiram menos alimento do que as não parasitadas, ocorrendo o inverso com as de 50 instar, as quais apresentaram maior digestibilidade a proximada e nenhuma diferença na conversão do alimento inge rido.

ZUÑIGA e TEJADA (1976) obtiveram uma maior eficiência protéica, biológica e econōmica, utilizando algas e milho variedade "Opaco-2", em substituição à caseina na criacão da fase larval de $H$. virescens. Segundo BREWER (1981), baseando-se nos indices de consumo e utilização de alimentos, a dieta ä base de farinha de soja e óleo de miTho foi suficientemente nutritiva para substituir, economicamente, a dieta à base de farinha de soja e germe de trigo. 0 mesmo resultado foi alcancado por MIHSFELDT et alii (1984), substituindo a dieta à base de caseinna e germe de trigo por outra à base de milho (variedade "Nutrimaiz"), ger me de trigo e levedura.

BREHER e KING (1979) compararam dietas à base de farinha de soja; avaliando a substituicão do agar por sabugo de milho, bem como diferentes recipientes para criacão da fase larval de H. virescens.

PRECETTI (1984) estudou a nutrição quantitati 
va do inseto em dietas naturais, constituidas por folhas de três cultivares de algodoeiro.

\subsection{Anormalidades morfológicas como critério de avalia cão para estudos de insetos em meios artificiais}

De maneira geral, os efeitos de dietas para insetos são medidos em termos de: razão de crescimento, de senvolvimento, reprodução, longevidade, características nu tricionais e anormalidades morfológicas (SINGH, 1977). Este ūitimo Ttem tem sido, particularmente, o mais utilizado e dentro de tais anormalidades, talvez devido à frequēn cia e caracteristicas facilmente notáveis, as deformações de asas na fase de pupa são as mais comentadas. Assim, MoRETI e PARRA (1983) utilizaram tais ocorrencias para controle de qualidade do vigor de populacões de H. virescens, mantidas em laboratōrio por gerações sucessivas. BERENBAUM (1986) chamou de sindrome pupal as anormalidades morfoló gicas em pupas, definindo como esclerotizacão incompleta, à quelas referidas as asas onde é vista uma faixa branca abaixo das mesmas. Näo obstante, a origem dessas deformacões, bem como a relação causa/efeito, não se encontram es clarecidas,podendo ser acarretadas pordoencas nutricionais e/ou aberrações e doenças genëticas (BENZ, 1963; HOUSE, 1963).

No primeiro caso, a maior dificuldade da pes- 
quisa reside na producão de efeitos caracteristicos, pois na maioria dos casos, a deficiencia de um nutriente causa, tão somente, a interrupcão do desenvolvimento ou a sobrevivēncia prolongada (Gordonl citado por HOUSE, 1963). - No segundo caso, a dificuldade reside na pequena quantidade de trabalhos cientificos existentes Steinhaus $^{2}$ citado por BENZ, 1963). Em se tratando de doen cas nutricionais, HOUSE (1963) revisou o assunto, tendo si do poucas as substancias nutritivas relacionadas com aque las deformaçoses. 0 autor concluiu que os sintomas de doen cas nutricionais, variam com as espécies, na dependéricia das suas diferenças metabölicas.

Quanto às tentativas de se explicar a deformacão de asas, citada anteriormente como uma doença nutri- . cional, BERENBAUM (1986) utilizou os trabalhos de alguns pesquisadores, entretanto, uns informaram que tal ocorrēncia era derivada de deficiencias de lipideos nos meios artificiais e que tal evento seria ausente em insetos mantidos em folhas, enquanto que outros, atribuiram o fato a a-

${ }^{1}$ GOROON, H.T. Minimal nutritional requirements of the german roach, Blatella germanica L. Annals cof the New york Academic Science, 77:290-301, 1959.

2 STEINHAUS, E.A. Noninfections disease: an area of neglect in insect pathology. Journal of Insect Patholoay, Ber keley, 4,i-viii, 1962. 
leloquímicos presentes nas dietas. No entanto, o sintoma também foi obtido, pelos pesquisadores citados, em insetos mantidos sobre folhas livres de aleloquimicos, não - sendo, ora em dietas controladas contendo estas substâncias, ora em pulverizacões no campo, de aleloquimicos, que haviam produzido o efeito desejado quando incorporado em dietas artificiais.

BENZ (1963) revisou a literatura sobre aberracões e doenças genéticas, definindo uma terminologia apropriada. Assim, denominou de aberração qualquer variacăo fenotipica produzida por fatores ambientais ou por mudanças no material genētico, sendo então, chamadas de aberraçoes geneticas. No entanto, se a aberracão for nociva ao inseto, o autor chamou-a de doenca, e se trans mitida hereditariamente, de dónça genētica, salientando ainda, a dificuldade da distincão entre as duas categorias, uma vez que alguns fatores hereditārios são inofensivos em um ambiente e nocivos em outro (doença genética condicionada), e que algumas doenças descritas co mo variaçoses morfolōgicas, não letais, são denominadas de malformações genéticas.

Por outro lado, podem ocorrer interacões entre doencas nutricionais e problemas genéticos, dificultando ainda mais a caracterizacão da causa de um sintoma, como por exemplo: a formação do pigmento marrom dos o1hos de Drosuphila melanogaster Meigen, 1830, 
pode ser impedida por mutação dos genes que controlam aquele caráter, o qual ocorre atravēs de conversäo do trip tofano no precursor do pigmento, a quiunerina (BENZ, 1963). Entretanto, Kanehisal citado por HOUSE (1963), enfo cou este problema pelo lado nutricional, relacionando-o sim plesmente. com o metabolismo do triptofano.

Segundo ROBINSON (1971), para se estudar aberrações, faz-se necessārio um programa de acasalamento consanguineo, bem planejado. Este autor relacionou aberracões ocorridas em espécies de lepidōpteros, com os respectivos genes envolvidos.

\title{
2.5. Controle de qualidade em gerações sucessivas
}

\begin{abstract}
Segundo KOGAN (1986), em qualquer programa de criação de insetos sob condicões artificiais, é essencial que os mesmos preservem as caracteristicas genotipicas e fenotipicas que possam representar as populacões sel vagens,
\end{abstract}

${ }^{1}$ KANEHISA, T. Relation between the formation of melanotic tumors and tryptophane metabolism involving eye-colour in Drosophila. Annotationes 200l. Japan, 29:97$100,1956$. 
Boller e Chambers ${ }^{1}$, citados por PARRA (1986), relacionaram parāmetros biológicos e de comportamento, como componentes de qualidade cuja importäncia relativa varia de acordo com o objetivo da criação. A variabilidade que pode ocorrer em uma populacão de laboratōrio, em relacão àquela da natureza, pode ser devida a mudancas genéticas por tēcnicas de manipulação, qualidade nutricional da dieta, bem como, alteracões fisicas do ambiente (Ko GAN, 1986). Não obstante, os efeitos dessas variacões podem ser utilizados no monitoramento da criacão, através de métodos diversos e compativeis com os seus objetivos. Assim, para as atividades rotineiras de laboratörio, podem ser avaliadas nas gerações sucessivas, alterações nas caracteristicas biolögicas e fenotipicas do inseto (PARRA, 1986).

I BOLLER, E.F. è CHAMBERS, D.L. Quality aspects of massreared insects. In: RIDGWAY, R.L. e VINSON, S.B. ed. Biological Control by augmentation of natural enemies. New York, Plenum Press, 1977. p. 219-235. 


\section{MATERIAL E METODOS}

o trabalho foi desenvolvido nos laboratórios de Biologia do Departamento de Entomologia da Escola Superior de Agricultura "Luiz de Queirōz", Universidade de São Paulo, Piracicaba, SP, sendo conduzido à temperatura de $24 \pm 6^{\circ} \mathrm{C}$, umidade relativa de $70 \pm 10 \%$ e fotofase de 14 ho ras.

Adotou-se o delineamento estatistico inteira mente casualizado, comparando-se o desenvolvimento de Heliothis virescens (Fabr., 1781) em 5 gerações sucessivas, com base em parāmetros biológicos e indices nutricionais (WALDBAUER, 1968 e SLANSKY e SCRIBER, 1982), em quatro die tas artificiais com as seguintes fontes proteicas: à base de farinha de soja e germe de trigo (SHAVER e RAULSTON, 1971); feijão cozido e levedura de cerveja (BOWLING, 1967); farinha de milho, germe de trigo elevedura de cerveja (POI TOUT e BUES, 1970) adaptada por MIHSFELDT (1985); e como padrão, a dieta à base de caseina e germe de trigo (BERGER, 1963), adaptada por MORETI e PARRA (1983) para as con dicões brasileiras. (Tabela 1). Para facilidade de redacão, convencionou-se denominar as dietas de: "SGT", "FL", "MGTL" 
e "CGT", que são as iniciais das respectivas fontes protëicas.

As dietas foram preparadas segundo as técnicas descritas por PARRA (1979). Como recipientes para as dietas, utilizaram-se tubos de vidro de $2,5 \mathrm{~cm}$ de diāmetro por $8,5 \mathrm{~cm}$ de altura, tendo como tampa algodão hidrōfugo. Este conjunto foi esterilizado em estufa a $100^{\circ} \mathrm{C}$ por uma hora, transferindo-se em média, 12,58 $\pm 0,70$ gramas de dieta para cada tubo e procedendo-se então a uma nova esterilização por igual período de tempo, em cāmara assēptica modelo "PLANALSUCAR" (MENDES, 1980).

Utilizaram-se 100 tubos por tratamento, sendo considerado cada tubo, uma repeticão.

\subsection{Parāmetros biológicos estudados}

\subsubsection{Fase de 1arva}

A população inicial foi obtida de ovos de H. virescens, mantida em laboratōrio sob condicões não con troladas e criadas em folhas de algodoeiro por geraçoes sucessivas.

As lagartas récem-eclodidas foram transferi das, individualmente, para os tubos com dietas. Cada tratamento foi acondicionado em estantes, que permitiam a in clinaça dos tubos para facilitar o escoamento de āgua e 
consequentemente, diminuir a possibilidade de contaminação por microorganismos. Estes tratamentos constituíram a gera cão $F_{T}$ de laboratōrio, sendo avaliados os seguintes parāmetros:
a. duração mëdia da fase;
b. viabilidade da fase.

\subsubsection{Fase de pupa}

As pupas foram separadas por sexo (BUTT e CANTU, 1962), pesadas com 24 horas de idade e individual $\underline{i}$ zadas em tubos de vidro, idēnticos aos descritos anterior mente. Observaram-se os seguintes itens:
a. duração média da fase (machos e fēmeas);
b. peso mëdio de pupas (machos e fēmeas);
c. $\operatorname{razão}$ sexual $\left(r s=q / q+\sigma^{\circ}\right)$;
d. aberrações (alterações morfolōgicas);
e. viabilidade da fase.

\subsubsection{Fase de adulto}

os casais foram formados com individuos morfologicamente normais, emergidos no mesmo dia, mantidos em gai.olas de tubo de PVC com $10 \mathrm{~cm}$ de diametro por $22 \mathrm{~cm}$ de altu ra e alimentados com solucão de mel a $10 \%$ fornecida em recipiente de vidro, através de pavio de algodão (rolo den- 
t.a1) parcialmente imerso na solução.

Aspartes superiores e inferiores das gaio-

las foram fechadas, respectivamente, com material plàstico transparente e placa de petri forrada com papel filtro. A face interna da gaiola e a externa do recipiente de alimentação foram revestidas de papel jornal, como subs trato de postura.

Umedeceram-se as gaiolas diariamente, observando-se os seguintes itens:

a. período médio de pré-oviposição;

b. período médio de postura;

c. nümero médio de ovos por fêmea;

d. longevidade média de machos e fêmeas.

\subsubsection{Fase de ovit}

Obtidas as posturas, tomaram-se aliquotas de no máximo, 100 ovos por postura, por dia. Estas foram desinfestadas, por imersão em formaldeido a $5 \%$ por cinco minutos, e àgua destilada por dez minutos, quanto então foram transferidos para placas de Petri, contendo um chumaço de algodão hidrófilo mantido umedecido, diariamente. As placas foram vedadas com filme transparente de PVC ("MAGIPACK"). A incubação deu-se em càmara climatizada regulada a $25 \pm 1 \circ \mathrm{C} ; 70 \pm 10 \%$ de umidade relativa e fotofase de 14 horas. Foram observados os parâmetros: 

a. período mēdio de incubação;
b. viabilidade mëdia da fase.

\subsection{Indices nutricionais}

As determinacões foram feitas durante a geração $F_{2}$ com lagartas no "māximo desenvolvimento", nas die tas "CGT" e "MGTL". Os outros tratamentos (dietas) foram eliminados, por näo produzirem insetos com caracteristicas biolōgicas desejāveis à sua utilização. Considerou-se "mäximo desenvolvimento" o momento no qual o inseto deixou de se alimentar, comecando a raspar a dieta para formacão da câmara pupal.

$$
\text { Para cālculo de consumo e utilizacão do ali- }
$$
mento, foram determinados os seguintes indices nutricionais em peso de matēria seca (WALDBAUER, 1968; SLANSKY e SCRIBER, 1982).

1. Digestibilidade aproximada

$$
A D=\frac{\text { consumo } 1 \text { iquido }}{\text { consumo bruto }} \times 100
$$

2. Eficiēncia de conversão do alimento ingerido

$$
E C I=\frac{\text { ganho de biomassa }}{\text { consumo bruto }} \times 100
$$


3. Eficiència de conversão do alimento digerido

$$
E C D=\frac{\text { ganho de biomassa }}{\text { consumo } 1 \text { iquido }} \times 100
$$

4. Custo metabólico

$$
C M=100-E C D
$$

Consumo bruto $=$ peso seco do alimento consumido. Consumo 1 íquido = consumo bruto - peso seco das fezes. Ganho de biomassa = peso seco do inseto no mäximo desenvolvimento.

Para se determinar esses parāmetros, iniciouse a avaliação com 60 lagartas por dieta. Ao atingir o "mäximo desenvolvimento", as lagartas foram mortas em "freezer" e as fezes separadas do alimento não consumido. Estes très componentes (lagartas, fezes e alimentos), foram postos a secar por 30 dias, em estufa mantida a $55^{\circ} \mathrm{C}$, sendo en tão pesados.

Para obtenção do ganho de biomassa das lagartas, considerou-se o seu peso inicial igual a zero.

Uma arquota com 10 tubos, somente com dietas, sofreu o mesmo processo de secagem para se estimar o percentual de āgua do meio. Com este fator de correção, cal culou-se o peso seco inicial da dieta fornecida às lagartas. 


\section{RESULTADOS E DISCUSSÃo}

\subsection{Fase de larva}

As duracões médias desta fase, dentro dos res pectivos tratamentos, não apresentaram grandes variacões ao Tongo das geracões estudadas, ocorrendo, entretanto, um alongamento excessivo do período larval nas dietas à base de soja-germe de trigo ("SGT") e feijão-levedura ("FL"). Isto determinou a interrupcão das criacões na lạ e $2 a$ geração, respectivamente, devido a elevada mortalidade ocorrida nas mesmas. Por outro lado, as dietas à base de milho-germe de trigo-levedura ("MGTL") e caseina-germe de trigo ("CGT"), pro piciaram estudos por 5 geracões sucessivas. Os resultados encontrados, bem como os registrados na literatura, são apresentados nas tabelas 2 e 3 , respectivamente, e por facilidade de entendimento, os tratamentos serãodiscutidos dois a dois. 


\subsubsection{Dietas a base de soja-germe de trigo ("SGT") e feijão-1evedura ("FL")}

Embora não tenha sido registrada a maior dura ção da fase larval na dieta "SGT" (Tabela 2), ela mostrou-se inadequada pela baixa viabilidade obtida nesta fase (5\%) o que, provavelmente, deveu-se tanto a fatores independentes como a fatores dependentes da dieta.

Em relação ao primeiro caso (fatores independentes), observou-se que $11 \%$ das lagartas morreram em 24 ho ras apōs a eclosão, fato que pode ser atribuído a alteraçöes embrionārias e/ou a problemas ocorridos durante a mani pulação, na transferência das lagartas para os tubos com die ta.

A segunda situação (fatores dependentes) pode ser encarada sob os seguintes aspectos: propriedades fisicas indesejadas e/ou caracteristicas nutricionais inadequa das da dieta. Em relacão às caracterīsticas fīsicas, a subs tituição do agar por sabugo de milho moỉdo, no presente tra balho, provocou a morte de $12 \%$ das lagartas por afogamento. Este fato jā fora observado por RAULSTON e SHAVER (1970) e atribuído à excessiva liberação de àgua por aquele material, adicionado à dieta de BERGER (1963).

No que diz respeito a caracteristicas nutricionais, o excesso de āgua poderia ter acarretado um atraso no desenvolvimento do inseto, bem como uma redução na viabi 
lidade larval (RAULSTON \& SHAVER, 1970). No entanto, SHAVER e RAULSTON (1971), utilizando dietas à base de "SGT" com sabugo de milho moido, obtiveram uma alta viabilidade larval (81-92\%), sem constatarem efeitos deletérios / aparentes, sobre o crescimento e desenvolvimento de Heliothis virescens. Não obstante, no presente trabalho, alēm da elevada duração da fase 1 arval, ocorreu uma perda de $72 \%$ das 1 agartas devido a deformacões cefälicas e anomalias por ocasião da ecdise, que impediram a liberação total da exūvia. Estas aberrações foram caracterizadas principalmente por:

a. expansão da fronte e intumescimento das mandibutas;

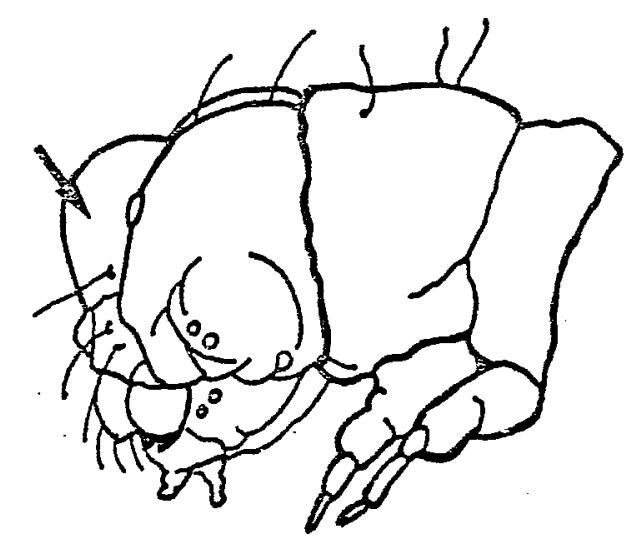


b. descaracterização do vērtice;

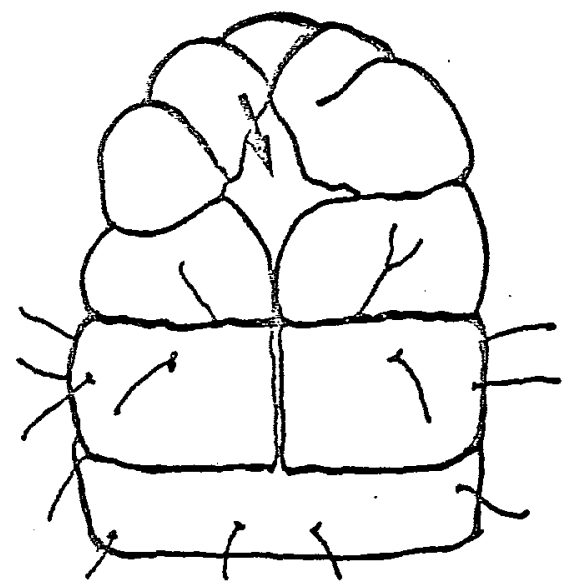

c. fusão de cápsulas cefālicas na ecdise, ocorrendo superposicão de exūvias;

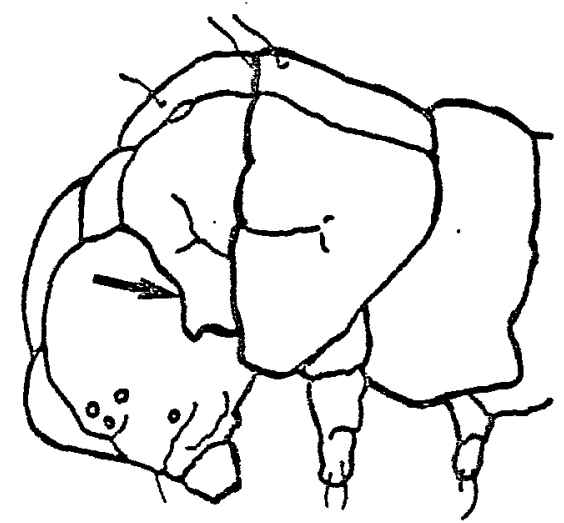

os resultados obtidos realmente sugeriram uma inadequacão nutricional da dieta, apoiado principalmente na teoria de Gordon ${ }^{2}$, citado por HOUSE (1963), a qual enuncia que: - "Deficiēncias nutricionais geralmente causam uma paralização do crescimento, alongando o período de de-

I GORDON, H.T. Minimal nutritional requirements of the German roach, Blatella germanica L. Annals of the New York Academic Science, 77:290-351, 1959. 
senvolvimento, ou produzem alta mortalidade". Entretanto, pode-se supor que a deficiēncia nutricional em questão, pode ter sido provocada por alteracões físicas da dieta.

A teoria de inadequacão nutricional também pode ser aplicāvel à dieta "FL", a qual proporcionou a ma or duracão da fase larval, nas duas geracões obtidas, não existindo diferencas significativas entre as mëdias alcançadas em ambas as gerações (Tabela 2). Essas médias, por sua vez, foram totalmente discrepantes da literatura em ge ral, principalmente no tocante à dieta formulada com feijão (Tabela 3), o que talvez seja devido a questões varietais, pois PARRA e CARVALHO (1984) observaram um comportamento diferencial de Spodoptera frugiperda (J.E. Smith, 1797 ) em dietas formuladas com diferentes variedades dessa leguminosa.

As perdas na fase larval, durante a primeira geração na dieta "FL", totalizaram $70 \%$, tendo $2 \%$ de mor talidade ocorrido em 24 horas após a eclosão e $68 \%$ em meio ao desenvolvimento. Consequentemente, embora apresentando maior viabilidade larval do que aquela encontrada na die ta "CGT", proporcionando inclusive uma segunda geração, a dieta "FL" e a dieta "SGT" foram eliminadas dos demais experimentos, principalmente devido ao alongamento excessivo do período larval. 


\subsubsection{Dietas à base de millho-germe de trigo-le- vedura ("MGTL") e caseina-germe de trigo ("CGT")}

As menores mëdias de duração da fase larval foram obtidas nestas duas dietas, sendo, a menor delas, apresentada pelos insetos mantidos na dieta "MGTL", em todas as gerações (Tabela 2). A ém disso, os intervalos de variacão indicaram que esta dieta promoveu um crescimento mais uniforme e concentrado, proporcionando condicões para um melhor planejamento de criacões de laboratōrio (F gura 1). Assim, a dieta "MGTL" produziu uma mëdia entre ge racões prōxima àquelas registradas por alguns autores, no entanto, inferiores àquelas observadas por SouzA (1981) e MORETI e PARRA (1983), nas condicões brasileiras (Tabelas 2 e 3). Na dieta "CGT", a média obtida foi muito superior às citadas, inclusive àquelas dos autores anteriormente re latados e que trabalharam em condições de ambiente idênticas, sugerindo, pois, que a discrepancia dos resultados po de ser devida, entre outros fatores, a variacões intra-espe cíficas e na qualidade dos componentes da dieta.

Esta variação na qualidade dos componentes $\bar{e}$ muito importante, especialmente para as condicões brasileiras, pois, dado ao elevado custo dos ingredientes das dietas artificiais, nem sempre hā possibilidades de se trabalhar com componentes puros (para anālise); então opta-se 
por produtos de qualidade inferior e que em alguns casos, contêm traços de substāncias (impurezas) que podem prejudi car o normal desenvolvimento do inseto.

os percentuais das perdas ocorridos nos dois tratamentos podem ser observados na tabela 4 , onde em ter mos totais,os maiores valores foram obtidos na primeira ge ração em ambas as dietas, sugerindo uma provāvel adaptação ao novo substrato ao longo das gerações.

$\mathrm{Na}$ dieta "MGTL", o componente que mais afetou a viabilidade da fase foi o relativo à "mortalidade em pré-pupa", seguido de perto por um elevado percentual de mortes em meio ao desenvolvimento larval (Tabela 4). No pri meiro caso, embora sem uma anālise patológica detalhada, todos os insetos apresentaram sintomas de infeccão virōtica, mostrando uma coloração escura e flacidez corpörea, o que certamente, mascarou a influēncia nutricional da dieta no desenvolvimento do inseto.

Por outro lado na dieta "CGT", a mortalidade larval em meio ao desenvolvimento foi a maior responsāvel pelas perdas, embora estas tenham sido computadas, tam bém, em dietas contaminadas com microorganismos (Tabela 4), levando à subestimação do parâmetro viabilidade. Não obstante, este valor foi semelhante, na mëdia entre geracões, nos dois tratamentos e discrepante da literatura em geral (Tabela 3).

Assim, os resultados sugeriram que na dieta 
"MGTL", a viabilidade da fase larval sofreu maior influēncia de fatores independentes das suas qualidades nutricionais, pois, caso não fossem computadas as mortalidades em prē-pupa, atribuīidas a uma provāvel infeccão virōtica, as viabil dades seriam comparáveis às registradas na literatura. Com a segunda dieta("CGT")ocorreria algo semelhante, se descontadas as contaminaçöes do meio por microorganismos, o que certamente alterou as caracterîsticas dietēticas e nutricionais desse substrato, influenciando na sua utilizacão pelos inse tos. Essas considerações, encontram fortes evidēncias nos resultados demonstrados pelos indices nutricionais (Tabela 15), onde a dieta "MGTL" promoveu um crescimento muito supe rior àquele obtido na dieta "CGT", que é uma dieta nutricionalmente consagrada nas criacões de $H$. virescens.

Tomando-se por base estes fatos, excluindo-se portanto o parāmetro viabilidade, a dieta "MGTL" mostrouse superior em relação à dieta "CGT", por não apresentar as contaminaçöes por microorganismos, o que concorre no seu cre denciamento para utilização nas condições brasileiras.

\subsection{Fase de pupa}

Como a sexagem foi realizada baseando-se em caracteres morfolögicos da pupa, a razão sexual foi determi nada nesta fase. Em ambas as dietas ("MGTL" e "CGT"), ocorreu uma pequena variabilidade deste parāmetro gerando, en- 
tretanto, médias totais semelhantes a 0,5 (Tabela 5). Os resultados obtidos indicam a qualidade nutricional das duas dietas, tomando-se como base a teoria de BHATTACHARYA e PANT (1976), onde $\bar{e}$ dito que: "Uma dieta pode ser caracterizada como nutricionalmente adequada, se no minimo a razão sexual for 0,5 e no mäximo, o nümero de fēmeas exceder o de machos".

os pesos médios de pupas,incluindo machos e fémeas, observados nas duas dietas, encontram-se no intervalo de variação registrado na 1 iteratura, não tendo sido observa das diferencas em funçăo do sexo (Tabelas 6 e 7 ). Entretanto, aqueles produzidos pela dieta "MGTL" foram superiores em todas as geracões, alcancando um valor médio total, cerca de 1,45vezes major do que aquele obtido na dieta "CGT't (Ta bela 6). Esses resultados sugeriram que, neste trabalho, a dieta "MGTL" foi dieteticamente mais adequada ou melhor metabolizada. A segunda hipōtese pareceu a mais viāvel, em primeiro lugar devido ao fato que na literatura, a dieta "CGT", uma dieta padrão, apresentou peso de pupas semelhantes e até superiores àqueles produzidos neste estudo, pela dieta "MGTL". Em segundo lugar, pelo maior custo metabōlico da fase larval, observado na dieta "CGT" (Tabela 15). No entanto, não se pode deixar de levar em conta, que outros fa tores, tais como: qualidade dos ingredientes da dieta e base genētica da população, podem ter tido influēncias nesses resultados. 
Na duração da fase pupal, houve variacão entre as gerações 2, 4 e 5 nas duas dietas e apesar disto, as mëdias dos tratamentos foram muito próximas (Tabela 5). Esses resultados sugerem que não houve influēncia, pelo me nos detectāvel, da dieta larval naquele parâmetro, o que coincide com resultados observados na literatura, onde os valores apresentados são semelhantes aos encontrados neste trabalho e as variacões ocorrem entre os autores, e não en tre as dietas por eles utilizadas (Tabela 7 ).

A viabilidade de pupas foi um parâmetro irre gular ao longo das geracões, alcançando valores ora semeThantes, ora mais baixos que os registrados na literatura. Assim, a dieta "MGTL" apresentou a menor média total, enquanto que a obtida na dieta "CGT", assemelhou-se àquelas encontradas por alguns a.utores (Tabelas 8 e 7 ).

A mortalidade durante a fase pupal ocorreu principalmente em pupas com aberracões (Tabela 8), cuja a presenca em todas as geraçoes jā fora observada por MORETI e PARRA (1983) e considerada pelos autores, como um parāmetro importante na avaliação de dietas ou na medição do vigor de populações de laboratōrio. Como as pupas deformadas deram origem a adultos deformados ou não permitiram as suas emergéncias, o nümero real dos mesmos foi mascarado. Por este motivo e considerando que deformações morfológicas de adultos, podem ser causadas por fatores externos co mo a manipulação, deu-se preferēncia à discussão das aber- 
rações na fase pupal.

Em mēdia, as aberracões de pupas obtidas nas dietas "MGTL" e "CGT", foram cerca de 37,47 e 27,66\%, respectivamente. Estes dados foram diferentes daqueles obtidos por MORETI e PARRA (1983), que registraram uma média de $9,28 \%$ até a quinta geracão e de $12,23 \%$ até a oitava geracão, para $H$. virescens provenientes de lagartas mantidas na dieta "CGT" (Figura 2 ).

Dentre as causas citadas na literatura, que poderiam produzir aberracões e explicar esses resultados, encontram-se: fatores ambientais, nutricão, idade da criação de laboratōrio e variabilidade genética. A primeira cau sa foi descartada, pois, neste trabalho as condicõos de la boratōrio atendiam as exigēncias da espēcie. A segunda tam bëm não pareceu a responsāvel pelas aberraçöes, devido aos seguintes fatos:

1. A dieta "MGTL", quando comparada $\bar{a}$ dieta "CGT", apresentou indices nutricionais bastante elevados (Tabela 15);

2. MIHSFELDT et alii (1984) não encontraram diferencas significativas entre os valores nutricionais des sas duas dietas;

3. MORETI e PARRA (198.3), utilizando a dieta "CGT", obtiveram um percentual mëdio de deformacōes de pupas, 2,98 vezes menor do que o observado neste trabalho, na mesma dieta. 
Assim, a idade da criação e a variabilidade genētica pareceram ser as mais provāveis responsāveis pe1 a degeneração da população, jā que ambas estão intimamen te correlacionadas, sendo que, esta degeneracão pode ter sido antecipada em função das tēcnicas de manipulação da criação (KOGAN, 1986). Desta forma, algumas geracões foram iniciadas com ovos de uma mesma gaiola, o que fatalmen te aumentou a taxa de consagüinidade da população.

Analisando-se a presente pesquisa e os dados de MORETI e PARRA (1983) (Figura 2), observa-se que a fase de pupa obtida da primeira geracão de laboratório, apresentou um percentual de aberrações, na dieta "MGTL", 3,03 vezes superior ao encontrado na dieta "CGT", o qual, por sua vez, foi 1,81 vezes maior que o registrado por aqueles autores, na mesma dieta. Além disso, o parāmetro em questão foi extremamente variāvel, aumentando sua ocor rēncia bruscamente em determinadas gerações.

Avaliando-se em conjunto os dados obtidos, a Titeratura disponivel e o estabelecimento deste experimento, o fator que melhor poderia justificar os resultados encontrados, seria o relativo a variabilidade genética, pois a população inicial deste trabalho foi originăria de insetos mantidos por vārias geraçoes em laboratōrio, determinando assim, uma maior probabilidade de endogamia, o que talvez explique os elevados percentuais de aberracõos observados nas duas dietas. Essa hipōtese en- 
contra forte evidencia nos baixos percentuais encontra dos por MORETI e PARRA (1983), que iniciaram seu trabalho com material de campo e portanto, com maiores chances de diversificação da base genētica da criação.

A falta de nitidez na correlação entre - percentual de aberracões e o nümero de gerações, demonstrada pelas variacões numēricas ao longo destas, sugere que aqueles valores podem ser determinados pelo acaso e devido à falta de controle genético na criacão.

A dificuldade de se manipular aquele parâmetro residiu na falta de caracterização das aberrações, sendo as referēncias na 7 iteratura em pequeno número, meramente descritivas e contraditórias, impossibilitando, assim, um estabelecimento mais preciso da relacão causa/ efeito. Devido às características desse estudo, procurouse representar as aberracões encontradas, como um subs $\dot{i}-$ dio a trabalhos futuros, sem no entanto definir as verdadeiras causas. Essas aberrações ocorreram em insetos provenientes de todas as dietas, às vezes acompanhadas de tu mores lisos, de coloração negra e aspecto brilhante.

As principais deformacões em relacão a uma pupa morfologicamente normal (a), foram as seguintes: 
a. Pupa morfologicamente normal:

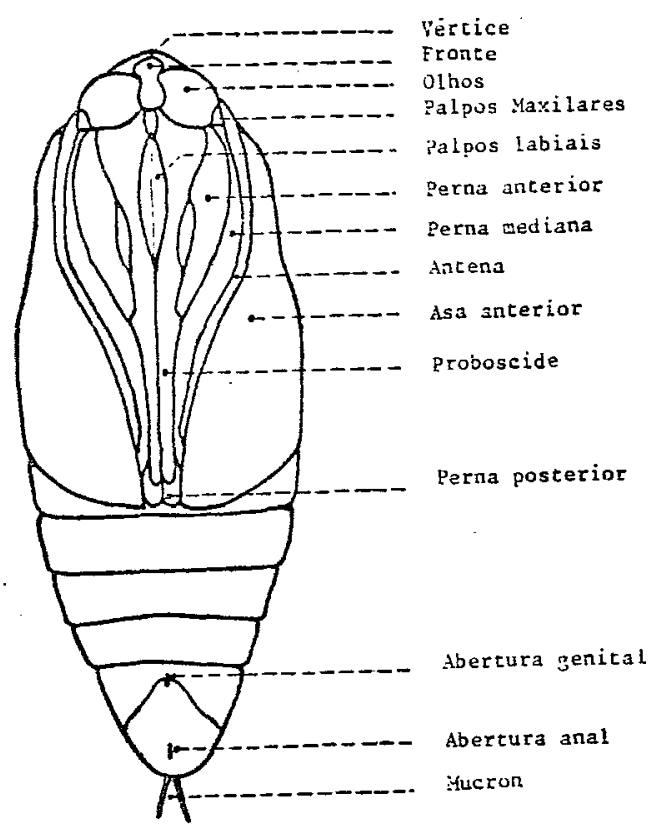

b. Retenção de caracteres morfológicos larvais:
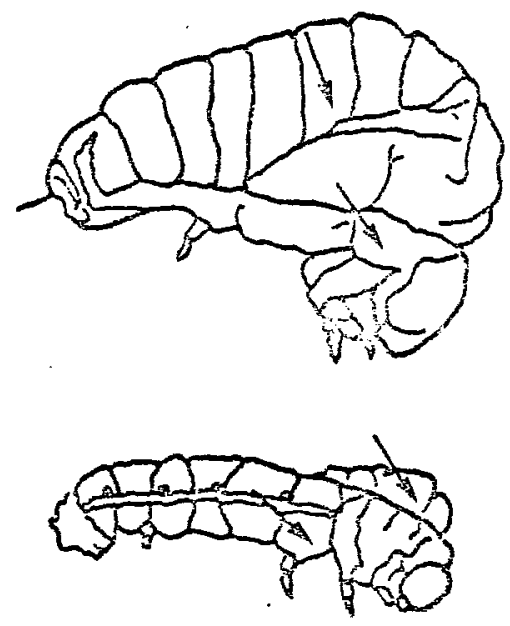

c. Atrofia das asas, caracterizada por expor 030 e 40 urōmeros, os quais se apresentam despigmentados na $\bar{a}-$ rea que deveria ser coberta por asas de tamanho normal. BE RENBAUM (1966) definiu tal situação como sendo "escleroti- 
zação incompleta", porém è fato que este sintoma encontrase associado à atrofia das asas;

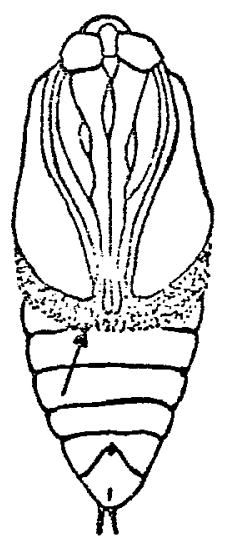

d. Atrofia e deformação das antenas;

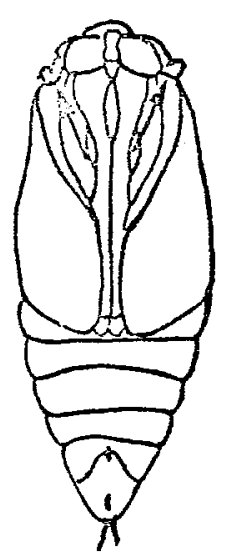

e. deformação de urōmeros, com descaracterização

da terminālia;

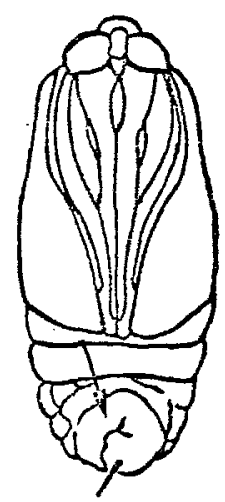


f. Deslocamento de ōrgãos de forma especīfica ou generalizada, acontecendo principalmente com antenas e pe cas bucais;

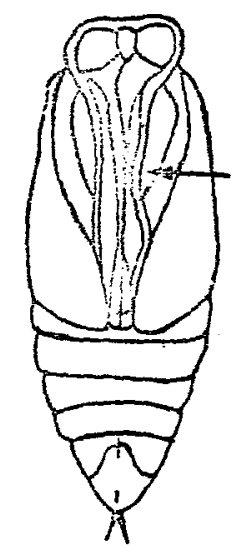

g. Tumores afetando asas e regiões circunvizinhas;
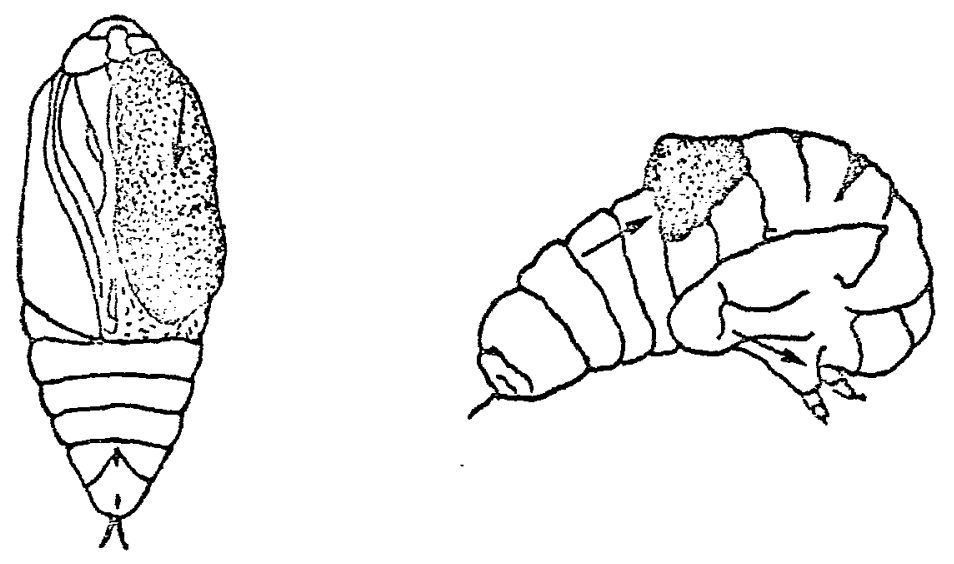
h. Formação de "bolsa aquosa" na asa.

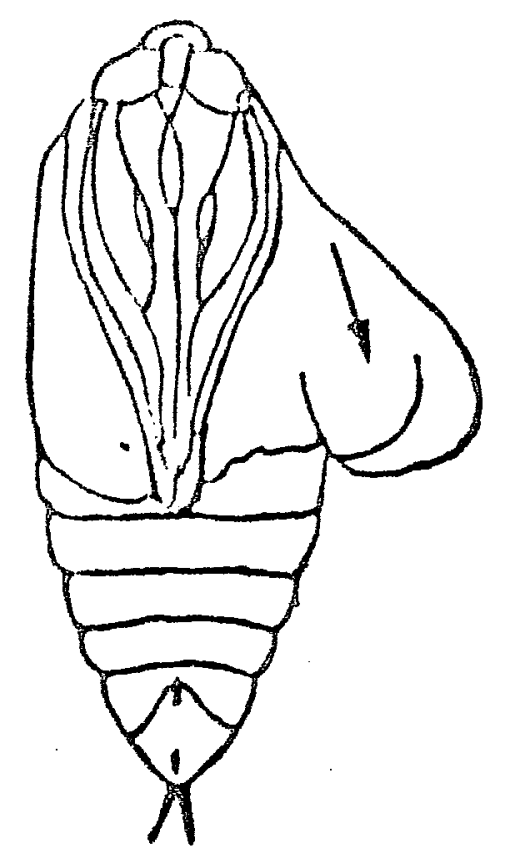

\subsection{Fase de adulto}

o perīodo de prē-oviposicão apresentou uma ligeira variação nas médias dentre as gerações estudadas (Figura 3 ), o que não influenciou nas médias totais, nos dois tratamentos (Tabela 9). Esses dados sugeriram que não houve influência da dieta larval neste parāmetro, o que con corda com a hipōtese de SOUZA (1981) e NADGAUDA e PITRE 
(1982), contrariando, no entanto, a de MORETI e PARRA (1983). o nümero médio de posturas por fémeas, diminuiu de maneira geral a cada geracão, exceto nas geracões $F_{3}$ e $F_{4}$, nas dietas "MGTL" e "CGT", respectivamente (Figura 3), sendo que, a primeira apresentou as maiores médias em todas as gerações (Tabela 9). Esses resultados, provavelmente, deveram-se a uma queda percentual do nümero de fémeas que colo $\underline{0}$ caram ovos, o que foi mais acentuado na segunda dieta (Figura 4). Entretanto existiu em ambos os tratamentos, uma rela cão direta entre o nümero de posturas e o nümero de ovos pro duzidos, em todas as geracões (Figura 3 ), sugerindo pois, que aquele parāmetro pode eventualmente definir a escolha de uma dieta artificial. A dieta larval pareceu influenciar no núme ro de posturas, uma vez que na dieta que gerou pupas mais pe sadas ("MGTL"), os adultos obtidos apresentaram uma tendēncia a realizar maior nümero de posturas e produzir maior quan tidade de ovos (Tabela 9; Figura 3).

0 nümero mêdio de ovos por fêmea entre as gera cões, em ambas as dietas, apresentou uma variabilidade coincidente com a literatura, demonstrando uma tendéncia decrescente ao rongo do tempo, mais acentuada na segunda dieta ("CGT") e ocorrendo os menores valores observados, nos dois tra tamentos e na ültima geração onde a viabilidade foi zero (Fi gura 3; Tabelas 9, 10 e 12). Esses resultados ocorreram em função de que $100 \%$ das fémeas acasaladas, ovipositaram até a terceira e segunda gerações nos tratamentos "MGTL" e "CGT", 
respectivamente, existindo a partir dessas geracões, um de clínio mais pronunciado na dieta "CGT" (Figura 4). Assim, a média total de ovos obtida entre os tratamentos foi cer ca de 1,91 vezes maior na dieta "MGTL", sendo ambas as médias ocasionalmente semelhantes às encontradas na literatu ra e superiores às observadas por SOUZA (1981) e MORETI e PARRA (1983), nas condicões brasileiras (Tabelas 9 e 10). As longevidades dos adultos foram semelhantes àquelas citadas na literatura, em ambas as dietas, sen do os maiores valores, observados nos adultos provenientes da dieta larval "MGTL" (Tabela 11), o que sugere uma provä vel influência desse meio. Entretanto esta influência pareceu casual, devido aquele parāmetro apresentar pouca variabilidade nos diferentes maios artificiais, usados em criacões de $H$. virescens (Tabela 10), alëm de não diferir em comparacões entre dietas naturais (folhas de algodoeiro) e artificiais (SOUZA, 1931; MORETI e PARRA, 1983) e en tre cultivares de algodoeiro (PRECETTI, 1984; CORREIA e VEN DRAMIM, 1986). No entanto, segundo HABIB e PATEL (1977), a longevidade de adultos é influenciada, quando se fornece diferentes örgãos vegetais, como dieta. Aparentemente, a dieta larval provocou diferenças na longevidade dos sexos, pois na dieta "MGTL" os machos viveram sempre mais que as fēmeas. 


\subsection{Fase de ovo}

o período de incubaça apresentou uma desprezivel variacão ao longo das gerações (Figura 3 ), o que pode ser confirmado pela igualdade numërica das mëdias totais (Tá bela 12). Estes resultados foram semelhantes aos encontrados na literatura (Tabela 13), sugerindo que a dieta larval e o nümero de geraçōes não influenciaram significativamente aquele parāmetro, podendo, isto, ser explicado através da constância das condicões de laboratörio (SOUJA, 1981; MO RETI E PARRA, 1983).

A viabilidade dos ovos foi extremamente varia vel, sendo os valores médios obtidos, parciais ou totais, inferiores àqueles encontrados na literatura, em ambas as dietas (Tabela 12). Segundo MORETI e PARRA (1983), este parāmetro é diretamente influenciado pela alimentação e pela diminuicão da variabilidade genética. No que diz respeito ao primeiro caso, os resultados obtidos, embora baixos, não sugeriram uma inadequação nutricional das dietas, uma vez que, a dieta "CGT", ē um padrão na criacão de H. virescens e a dieta teste "MGTL", apresentou, numericamente, a melhor performance biológica em todos os itens analisados. Portan to, baseado na conducão geneticamente estanque do experimento, os resultados obtidos deveram-se, provavelmente, a pequena base genētica da população inicial, diminuída ao longo das geracões por acasalamentos consanguineos, 0 que 
segundo RAULSTON (1975), reflete diretamente no comportamen to reprodutivo de H. virescens. Essa hipótese foi reforçada pela diminuicão, ao longo das gerações, do nūmero médio de posturas por fêmeas (Figura 3) e do aumento de nümero de fê meas com posturas inviāveis ( $F$ igura 5 ), com conseqüente reducão do número mēdio de ovos, por fēmea, e respectivas viabi lidades (Figura 3 ).

\subsection{Consumo e utilização das dietas "MGTL" e "CGT" por} lagartas de $H$, virescens

A comparação dos dados obtidos neste $\bar{i} t e m, ~ o \underline{b}$ servados nas tabelas 14 e 15 , com os existentes na literatú ra, torna-se dificil pois a maioria dos autores determinou os indices nutricionais por instar e na presente pesquisa, a determinaça foi feita para a fase larval como um todo. o consumo bruto em peso de matéria seca da dieta "MGTL", foi 1,44 vezes maior que o da dieta "CGT". Como a digestibilida de aproximada (AD) e a representacão percentual do consumo liquido sobre o bruto, observou-se que a dieta "MGTL", a mais consumida, apresentou a menor A.D. $(38,68 \%)$, eliminando portanto $61,32 \%$ do consumo bruto na forma de fezes. Por outro lado, a dieta "CGT", a menos consumida, apresentou um ligeiro equitiorio entre esses dois fatores, com uma de $50,19 \%$ e uma producão de fezes de $49,81 \%$. Assim, esses resultados sugeriram que a primeira dieta apresentou uma me 
nor proporcão de material nutritivo por quantidade de alimento ingerido, levando o inseto a um consumo maior. Apesar disso, pelos valores obtidos na ECI, observou-seque a dieta "MGTL" promoveu uma maior producão de biomassa.

A produção de biomassa, no total, foi 1,72 vezes maior na dieta "MGTL", onde mais da metade do consumo liquido, conforme a E.C.D., foi convertido, sendo $43,85 \%$ deste consumo destinado ao custo metabólico. Na segunda die ta ocorreu uma situaça inversa, sendo a maior parte daque le consumo utilizado no metabolismo energëtico e $36,83 \%$ (ECD) Convertido em peso corpóreo. Portanto, sob o ponto de vista de aproveitamento, a dieta "MGTL" apresentou a melhor performance. No entanto,o desiquilibrio mostrado na utilização, pelas lagartas, da dieta "CGT" (um substrato convencional), sugeriu que fatores independentes da dietética contribuitram para esses resultados, levando o inseto a um custo metabólico elevado, com comprometimento da produ cão de biomassa e da duração de determinados eventos biolögicos, como por exemplo a duracão da fase larval (Tabe1 as 14,15 e 2).

Assim, WALDBAUER (1968) enunciou que: "quantidades proporcionais da porcão digerivel (consumo líquido), são utilizadas ora para conversão em substāncias do corpo, ora para metabolizar energia de manutencão da vida". E CRÓCOMO (1983) levantou a hipōtese de que "caracteristicas indesejāveis do alimento e funcões fisiológicas 
que não resultam em crescimento, podem consumir energia". Neste trabalho poder-se-ia dizer que aquelas caracteristi cas levaram àquelas funções, uma vez que a dieta "CGT" desidratou mais rapidamente, apresentando, ainda, visivel aspecto de oxidacăo. Estes fatores, associados a outros não tão facilmente detectāveis, como a pureza dos ingredientes, podem ter afetado a utilização dos nutrientes pe 10 inseto, levando a maior parte do consumo 1 iquido à pro dução de energia de manutenção da vida.

\subsection{Considerações gerais}

A dieta "CGT", em função da sua condição de padrão convencional para as criaçoes de H. virescens, deveria ter apresentado neste trabalho, uma performance, no minimo, semelhante àquelas registradas na literatura. Entretanto a não ocorréncia deste fato, permitiu o questionamento sobre a validade da utilização de anālises estatỉsticas em um experimento onde o padrão apresentou dados que não expressaram verdadeiramente as suas caracteristi cas como tal. Portanto, optou-se pela não inclusão daquelas anāitises, pois, devido a discrepāncia dos resultados obtidos na comparação entre os tratamentos "CGT" e "MGTL", serviriam, tão somente, para constatação do ōbvio.

Quanto aos parāmetros biológicos analisados sugere-se que o período de incubação de ovos, o período 
de pré-oviposicão e a duração da fase de pupa, sejam descon siderados em trabalhos que visem a comparacão de dietas a tificiais para H. virescens, por não apresentarem nenhuma ou pequena variabilidade, e neste caso inexpressiva, em re lação à dieta larval.

Ainda, estabelecendo-se um paralelo entre os resultados biológicos e nutricionais obtidos ao longo desta pesquisa, comparando-se as dietas à base de farinha de mitho, germe de trigo e levedura de cerveja ("MGTL") e aquela composta de caseina e germe de trigo ("CGT"), podese concluir que a primeira delas foi a mais adequada para criacão de H. virescens em 1 aboratōrio, principalmente para as condiçoes brasileiras, pelos seguintes motivos:

- promoveu um encurtamento da fase larval de H. virescens em todas as gerações, com crescimento bastante uniforme, condição esta interessante para criações de insetos em laboratório;

- foi menos sensivel a contaminacão por microorganismos, os quais dependendo da extensão de ataque, podem ser limitantes à producão de insetos;

- proporcionou um maior peso de pupas, o que Tevou a um maior nūmero de posturas e quase o dobro do nūmero de ovos por fémea;

- promoveu maior ganho de biomassa, maior eficiēncia de conversão do ingerido (ECI) e digerido ECD proporcionando um bom desenvolvimento com baixo 
custo metabōifico $(100-E C D)$;

- apresenta um custo, obviamente, menor em relação à dieta convencionalmente utilizada para criar H. virescens.

Desta forma, a despeito de ter apresentado ba $\underline{i}$ xas viabilidades nas fases estudadas, esta dieta poderā ser utilizada para produção de H. virescens, sugerindo-se que se ja permitido um perĩodo de adaptação do inseto ao meio, no minimo por uma geração, e que a criação seja iniciada com o maior nümero possivel de indivỉduos, preferencialmente oriun dos do campo, a fim de minimizar a ação desfavorāvel de fato res genéticos sobre os resultados. 


\section{COHCLUSÕES}

Considerando-se os resultados obtidos na pre sente pesquisa com Heliothis virescens (Fabr., 1781), pode-se concluir que:

- Baseando-se em parāmetros biológicos, nutricionais e económicos, a dieta composta de farinha de mi Tho, germe-de-trigo e levedura de cerveja pode substituir a dieta convencional à base de caseina e germe-de-trigo, em criacões de $H$. virescens, nas condições brasileiras. 


\section{REFERENCIAS BIBLIOGRĀFICAS}

BHATTACHARYA,A.K. e PANT, G.B. Studies on the host plant relationships: Consumption and utilization profile in insects. Proceedings of Natural Academy of Science, A 11 ahabad, $\underline{46}(1,2): 273-301,1976$.

BECK, S.D. Resistance of plants to insects. Annual Review of Entomology. Palo A1to, 10:207-232, 1965.

BENZ, G. Genetic diseases and aberrations. In: STEINHAUS, A.E., ed. Insect Pathology, New York. Academic Press, $1: 161-185,1963$.

Berenbaum, M. Post ingestive effects of phytochemicals on insects: On paracelsus and plant products. In: MILLER, J.R. e MILLER, T.A. ed. Insect-plant interations. New York, Spring-Verlag Inc. 1986. p. 121-153.

BERGER, R.S. Laboratory techniques for rearing Heliothis spp. on artificial medium. A.R.S., United States Depart ment of Agriculture. Washington, 33-84, 1963. 4p.

BLEICHER, E. Importāncia relativa das principais pragas do algodoeiro no Brasil, através do tempo. In: Reunião Na- 
54.

cional do Algodão, 3, Salvador, 1982. Resumo. Campina Grande, EMBRAPA-CNPA, 1982. p. 175.

BOLDT, P.E.; BIEVER, K.D. \& IGNOFFO, C.M. Lepidopteran pests of soybeans: Consumption of soybean foliage and pods and development time. Jounnal of Economic Entomology. College Park, 68 (4): 480-482, 1975.

BOTTGER, G.T. Development of synthetic food media for use in nutrition studies of the European corn borer. Jounnal of Agricultural Reseanch. London, 65: 493-500,1942.

BOWLING, C.C. Rearing of two lepidopterous pests of rice on a common artificial diet. Annals of the Entomological Society of America. Columbs, 60(6): 1215-1216, 1967.

BREWER, F. D. Development of Heliothis virescens Dia trea sacchanalis on a soyflour-corn oil diet. Annals of the Entomological Society of America. Columbus, 74 (3): $320-323,1981$.

BREWER, F.D. e KING, E.G. Consumption and utilization of soyflour-wheat germ diets by Heliothis spp. Annals of the Entomological Society of America. College Park, 72 (3): $415-417,1979$.

BREWER, F.D. e KING, E.G. Consumption and utilization of a soyflour-wheat germ diet by larvae of the tobacco budworm parasitized by the tachinid Eucelatonia sp. Entomophaga, 25 (1): 95-101, 1980. 
BUTLER, G.D. Jr. e HAMILTON, A.G. Development time of Heliothis vinescens in relation to constant temperature. Envinonmental Entomology, Maryland, 5(4):759-760.1976.

BUTLER, G.D. Jr.; HAMILTON, A.G. e PROSHOLD, F.I. Developmental times of Heliothis virescens and $H$. subflexa in relation to constant temperature. Annals of the Entomological Society of America. Columbus, 72(2):263-266,1979.

BUTT, B.A. e CANTU, E. Sex determination of lepidopterous pupae. A.R.S., United State Department of Agriculture. Washington, no $33-75,7$ p., 1962 .

CHOU, Y.M., ROCK, G.C. e HODGSON, E. Consumption and utilization of chemically defined diets by Angynotaenia velutinana and Heliothis vinescens. Annals of the Entomological Society of America. College Park, 66(3): 627$632,1973$.

CORREIA, J.S. e VENDAMIM, J.D. Influência de cultivares de algodoeiro na biologia de Heliothis vinescens (Fabricius, 1781 ) (Lepidoptera, Noctuidae). Anais da Sociedade Entomológica do Brasil. Porto Alegre, 15(1): 48-59, 1986.

CRÓCOMO,B.W.Consumo e utilização de très diferentes gramíneas por Spodoptena Rnugipenda (J.E. SMITH, 1797) (LEPI DOPTERA-NOCTUIDAE). Piracicaba, 1983, $95 \mathrm{pp.} \mathrm{(Doutorado-}$ Escola Superior de Agricultura "Luiz de Queiroz"/USP.

DETHIER,V.G., BROWNE, L.B. e SMITH, C.N. The designation of chemicals in terms of the responses they elicit from 
56.

insects. Jounnal of Economic Entomology. College Park, 53 (1): $134-136,1960$.

DIKEMAN, N.R., LAMBREMONT, E.N. e ALLEN, R.S. Evidence for selective absorption of polyunsaturated fatty accids du ring digestion in the tobacco budworm, Heliothis virescens F. Jounnal of Insect Physiology, Great Britain,27: $31-33,1981$.

ENKERLIN, D. e LASTRA, N. Estudio comparativo de la biologia de Heliothis virescens (Fabricius) y Helicoperva zea (Boddie). Informe de Investigación, Escuela de Agricultura y Ganaderia, Monterrey, 11: 55-58, 1967/68.

FONSECA, J.P. da. A lagarta verde dos capulhos do algodoei ro. O Biológico, São Pau1o, 11 (4): 110-111, 1945.

FRAENKEL. G. The raison d'ètre of secondary plant substances. Science, Lancaster, 129: 1466-1470, 1959.

FYE, R.E. e POOLE, H.K. Effect of high temperature on fecundity and fertility of six lepidopterous pests of cotton in Arizona. A.R.S., United States Department of Agriculture. Washington, 131,8 p., 1971.

FYE, R.E. e SURBER, D.E. Effects of several temperature and humidity regimens on eggs of six species of lepitop terous pests of cotton in Arizona. Jounnal of Economic Entomology, Geneva, 64 (5): 1138-1142, 1971 . 
GARCIA, B.G. Mëtodo de Crianza artificial y massiva de He Liothis virescens J. Revista Peruana de Entomologia, Li $\mathrm{ma}, \underline{3}(1): 65-66,1960$.

GUERRA, A.A. Effect of biologically acctive substances in diet on development and reproduction of Heliothis spp. Jounnal of Economic Entomology, College Park, 63 (5): $1518-1521,1970$.

GUERRA, A.A. e BHUIHA, A.D. Nutrition of the tobacco budworm: an economical larval diet diet for rearing. Jounnal of Economic Entomology. College Park, 62(3): 643$646,1977$.

GUERRA, A.A. e OUYE, M.T. Hatch, larval development and adult longevity of four lepidopterous species after thermal treatment of eggs. Jounnal of Economic Entomology, College Park, 61 (1): 14-16, 1968.

GUILLOT, S.F. e VINSON, E.B. Effect of parasitism by Candiochiles nigriceps on food consumption and utilization by Heliothis vinescens. Journal of Insect Physiology, Great Britain, 19: 2073-2083, 1973.

HABIB, M.E.M. e PATEL, P.N. Biology of Heliothis virescens (Fabr., 1781) (Lepidoptera-Noctuidae) on two host plants in laboratory. Indian Jounnal of Agnicultunal Science. New Delhi, 47(11): 537-539, 1977.

HERRICK, G.W. Manual of injurious insects.New York, Henry Hilt, 1925. $489 \mathrm{p}$.

HOUSE, L.H. Nutritional diseases. In: STEINHAUS, A.E., ed. Insect Pathology. New York and London, Academic Press, 
1963, p. $133-155$.

JONES, R.L.; PERKINS, W.D. e SPARKS, A.N. Corn earworm: ef fects of temperature variations on a colony. Annals of the Entomological Society of America. 71:393-396. 1978.

KINCADE, R.T.; LASTER, M.L. e BRAZZEL, J.R. Damage to Cotton by the tobacco budworm. Journal of Economic Entomo logy. College Park, 6(4):1163-1164, 1967.

KLEIN, I. e KOGAN, M. Analysis of food intake, utilization and growth in phytophagous insects a computer program. Annals of the Entomological Society of America, College Park, $67: 295-297,1974$.

KOGAN, M. Plant resistance in pest management. In: METCALF, R.L. e LUCKMANN, W.H. ed. Introduction to insect pest management, New York, John Wiley e Sons, 1975. p. 103146.

KOGAN, M. Bioassays for measuring quality of insect food. In: MILLER, J.R. e MILLER, T.A., ed. Insect-plant interations. New York, Spring-Verlag Inc. 1986. p. 181-184.

KOGAN, M. e COPE, D. Feeding and nutrition associated with soybeans. Food intake, utilization and growth in the soybean 7ooper Pseudoplusia includens. Annals of the Entomological Society of America, College Park, 67:67$72,1974$. 
KOGAN, M. e PARRA, J.R.P. Techniques and applications of measurements of comsumption and utilization of food by phytophagous insects. In: BHASKARAN, G.; FRIEDMAN, S.; RODRIGUEZ, J.G. eds. Current topics in insect endocri nology and nutrition. New York, Plenum Publiching Corporation, $1981,337-352$.

LUKEFAHAR, M.J. e MARTIN, D.F. The effects of various lar val and adults diets on the fecundity and longevity of the bollworm, tobacco budworm and cotton leafworm. Journal of Economic Entomology, College Park, 59(2): $233-235,1964$.

MENDES, A.C. Métodos de criacão de parasitos da broca da cana-de-açücar Diatraea saccharalis (Fabricius, 1794). In: Congresso Brasileiro de Entomologia, 6, Campinas 1980. Anais. Campinas, Fundação Cargi11, 1980, $103-$ 132.

METCALF, C.L.; FLINT, W.P. e METCALF, R.L. Destructive and useful insects-their habits and control. $4 \mathrm{ed}$, New York, McGraw-Hi11, 1962. 1087 p.

MIHSFELDT, L.H. Comparação de dietas artificiais para a criação de Diatraea saccharalis (Fabricius, 1794) (Lepidoptera-Pyralidae). Piracicaba, 1985. 120 p. (Mestra do - Escola Superior de Agricultura "Luiz de Queiroz"/ USP). 
MIHSFELDT, L.H.; PARRA, J.R.P. e SERRA, H.J.P. Comparacão de duas dietas artificiais para Heliothis virescens (F. 1781). In: Congresso Brasiteiro de Entomologia, 9, Londrina, 1984. Resumos. Londrina, Sociedade Entomolōgica do Brasi1, 1984. p. 70 .

MONTEWKA, R.H.; PONGPONRANT, P. e FEARS, R.D. Rearing Toba cco budworm in the laboratory. Wayside, Mississipi, Dow Chemical, 1976, 6 p.

MORETI, A.C.C.C. e PARRA, J.R.P. Biologia comparada e controle de qualidade de Heliothis virescens (Fabr., 1781) (Lepidoptera - Noctuidae) em dietas natural e artificiar. Arquivos do Instituto Biológico, São Pauro, 50 $(1 / 4): 7-15,1983$.

MORGAN, A.C. e McDONOUGH, F.L. The tobacco budworm and its control in southern tobacco districts.Farmens Bulletin, Washington, n. 819.11 p., 1917.

NADGAUDA, D. e PITRE, H. Development, fecundity, and longe vity of the tobacco budworm (Lepidoptera: Noctuidae) fed soybean, cotton, and artificial diet at three temperatu res. Environmental Entomology, Maryland, 12(2):583$586,1983$.

PARRA, J.R.P. Biologia dos Insetos. Piracicaba, 1979. 383 p. (Apostila - Escola Superior de Agricultura Luiz de 
Queiroz).

PARRA, J.R.P. Métodos para medir consumo e utilização de alimentos por insetos. In: Congresso Brasileiro de Entomo logia, 6, Campinas, 1980. Anais, Campinas. RAMIRo, Z.A.; GRAZIA, J.; LARA, F.M. eds., 1980, 193-212.

PARRA, J.R.P. Criação de insetos para estudos com patógenos. In: ALVES, S.B. Coord. Controle Microbiano de Insetos. São Paulo, Editora Manole, 1986. p. 368-369.

PARRA, J.R.P. e CARVALHO, S.M. de. Biologia e nutrição de Spodoptera frugiperda (J.E. Smith, 1797) em meios artificiais compostos de diferentes variedades de feijão. Anais da Sociedade Entomológica do Brasil, Porto Alegre, 13(2):305-319, 1984 .

PATANA, R. Rearing cotton insects in the laboratory. Washington, USDA, University of Arizona Agricultural Experiment Stations, 1969, P.R.R. 108, 6 p.

POITOUT, S. e BUES, R. Elevage de plusieurs espēces de Tépidoptēres Noctuidae sur milieu artificiel riche et sur milieu artificial simplifié. Annales de Zoologie Ecologie. Paris. 2:79-91, 1970 .

PRECETTI, A.A.C.M. Biologia e nutricão quantitativa de Heliothis virescens (Fabr., 1781) (Lepidoptera: Noctuidae) em três cultivares de algodaeiro lGossypium hirsutum 
var. latifolium L.). Piracicaba, 1984. 122 p. (Mestrado - Escola Superior de Agricuttura "Luiz de Queiróz"/ USP).

RAULSTON, J.R, e SHAVER, T.N. A low agar casein - wheat germ diet for rearing tobacco budworm. Journal of Economic Entomology, Geneva, 63(6):1743-1744, 1970.

RAULSTON, J.R. B-vitamin supplements required for soyflour - wheat germ diet used in rearing tobacco budworms. Annals of the Entomological Society of America, Col1ege Park, 68(2):387-388, 1975 .

RAULSTON, J.R. e KING, E.G. Rearing the tobacco budworm, Heliothis virescens, and the corn earworm, Heliothis zea. In: KING, E.G. e LEPPLA, N.C. ed. Advances and challenges in insect rearing. New orleans, Agricultura1. Research Service, U.S. Department of Agriculture, 1984 , p. $167-175$.

REESE, J.C. The effects of plant biochemicals on insect growth and nutritional physiology. In: HEDIN, P.A. ed. Host-plant resistance to pests, Washington, American Chemical Society, 1977, p. 129-152. (Symposium sēries, $62)$.

ROBINSON, R. Lepidoptera genetics. Hungary, Pergamom Press, 1971. $687 \mathrm{p}$. 
SANG, J.H. Circunstances affeting the nutritional requiriments of Drosophila melanogaster. Annals of the New York Academic Science, New York, 77:352-365, 1959.

SHAVER, T.N. e LUKEFAHAR, M.J. Effect of flavonoid pigments and gossypol on growth and development of the bol 1 worm, tobacco budworm and pink bollworm. Journal of Eco nomic Entomology. College Park, 62(3):643-646, 1969.

SHAVER, T.N.; LUKEFAHAR, M.J. e GARCIA, J.A. Food utilization, ingestion, and growth of larvae of the bollworm and tobacco budworm on diets containing gossypol. Journal of Economic Entomology, College Park, 63(5): $1544-$ 1546,1970 .

SHAVER, T.N. e RAULSTON, J.R. A soybean - wheat germ diet for rearing the tobacco budworm. Annals of the Entomolo gical Society of America, Washington, 64(5): 1077-1079, 1971 .

SHOREY, H.H. A simple artificial medium for the cabbagelooper. Journal of Economic Entomology, Geneva, 56:536-537, 1963.

SHOREY, H.H. e HALE, R.L. Mass-rearing of the larvae of nine noctuid species on a simple artificial medium. Jour nal of Economic Entomology, Geneva, 58(3):522-524, 1965.

SINGH, P. Artificial diets for insects, mites and spiders. New York, IFI/Plenum, 1977. $718 \mathrm{p}$. 
SINGH, P.e MOORE, R.F.eds. Handbook of insect rearing. Amster dam, Elsevier Science Publishing. Company Inc., 1985. $2 V$.

SLANSKY Jr.,F.e RODRIGUES, J.G.eds.Nutritional Ecology of Insects, Mites, Spiders and Related Invertebrates. USA, John Wiley \& Sons Inc. 1987. $1016 \mathrm{p}$.

SLANSKY Jr., F. e SCRIBER, J.M. Selected bibliography and summary of quantitative food utilization by immature in sects. Bulletin of Entomological Society of America, Wa shington, $28(1): 43-55,1982$.

SOUZA, A.R.E. Biologia comparada de Heliothis virescens (Fabr., 1781) (Lepidoptera: Noctuidae) a diferentes tem peraturas em meios natural e artificial. Piracicaba, 1981. 87 p. (Mestrado - Escola Superior de Agricultura "Luiz de Queirōz"/USP).

SULLIVAN, W.N.; CAWLEY, B.M.; OLIVER, M.; HAYES, D.K. e MCGUIRE, J.U. Manipulating the photoperiod to damage insects. Nature, London, 221(4):60-61, 1969.

SZUMKOWSKI, W. Recomendaciones para el combate de las plagas del algodonero, segun los resultados de los estudos biologicos. Agronomie Tropicale, Maracay, 13(4):273$290,1954$. 
VANDERZANT, E.S.; RICHARDZON, D.C. e FORT Jr., S.W. Rearing of the bollworm on artificial diet. Jounnal of Economic Entomology, College Par, 55 (1): 140, 1962 .

WALDBAUER, G.P. The comsumption and utilization of food by insects. Advances in Insect Physiology. London, $\underline{5}$ : $229-$ 228,1968 .

WALDBAUER, G.P. Food utilization. In: RODRIGUEZ, J.C., ed. Insect and mite nutnition, Amsterdan, 1972, p. 53-55.

ZŨNIGA, G.A. e TEJADA, L.0. Algas y Maiz 0paco-2, dos fuen tes de proteinas adecuadas y economicas para crias de Heliothis virescens $(F a b$.$) . Folia Entomologica Mexica-$ na, México, 36: $33-34,1976$. 


\section{APENDICES}



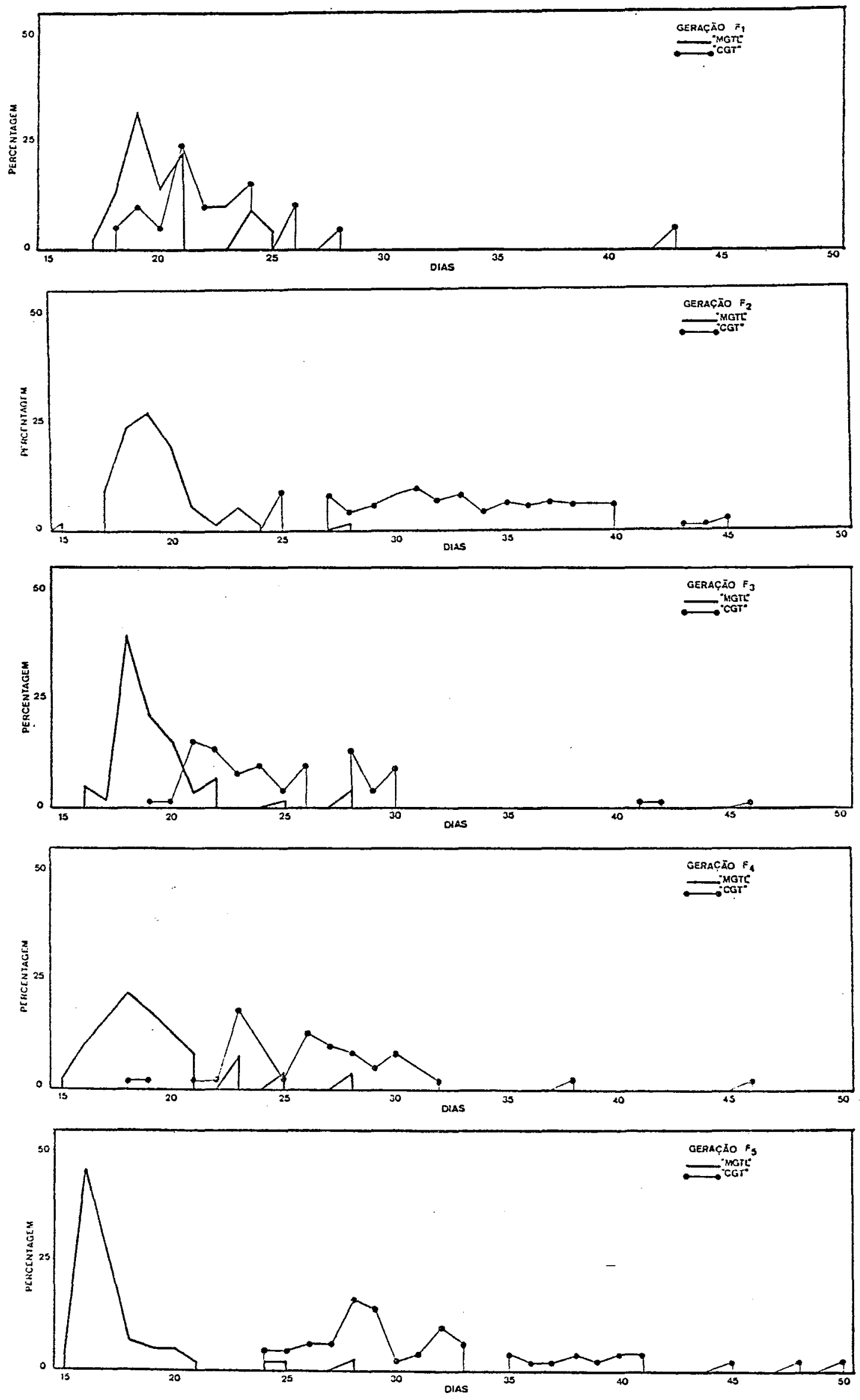

FIGURA 1. Percentual de lagartas de H. virescens, mantidas em duas dietas artificiais, que completaram a fa se larval e respectivas duracões. Temperatura de $24 \pm 6^{\circ} \mathrm{C}$, UR de $70 \pm 10 \%$ e fotofase de 14 horas. 


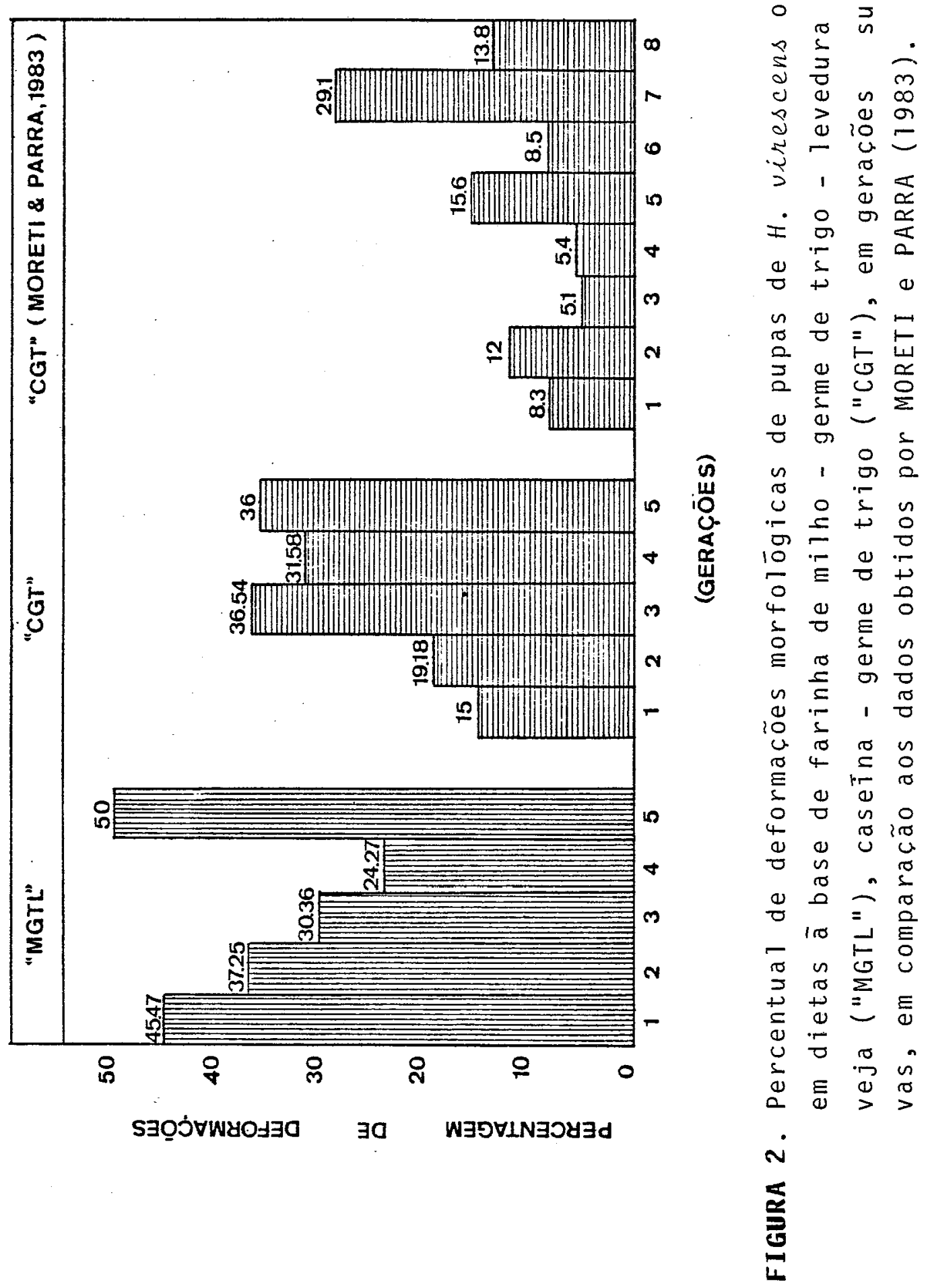




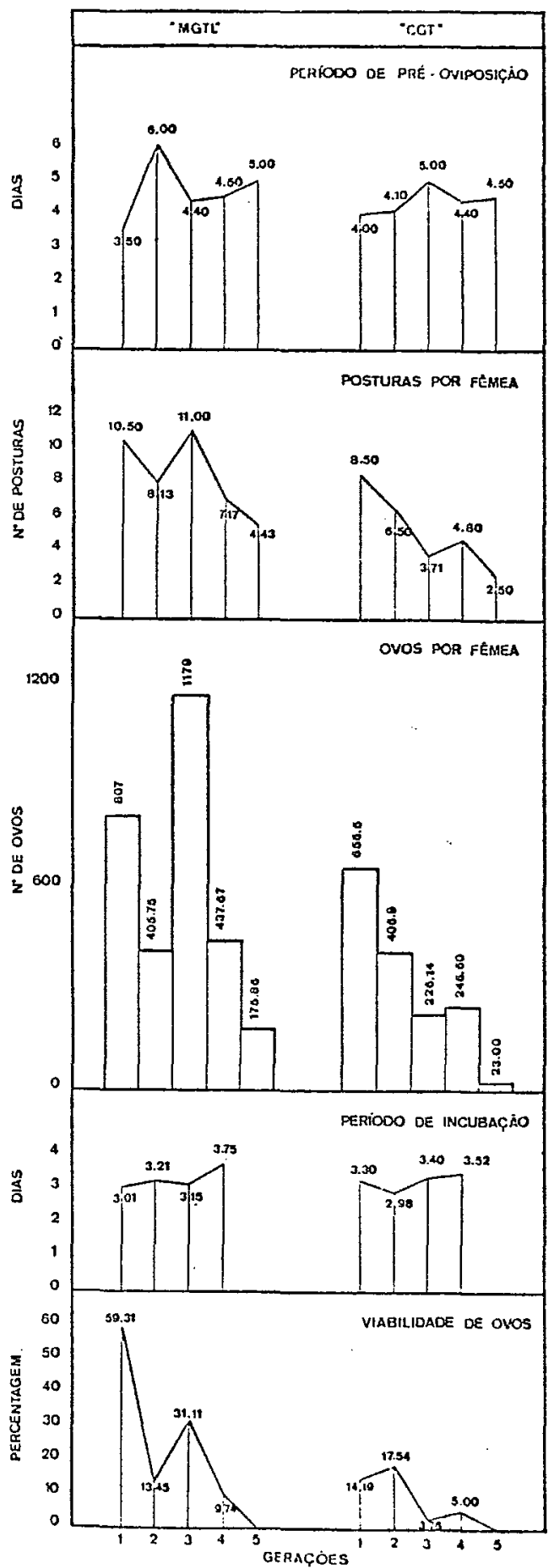

FIGURA 3. Parāmetros reprodutivos, perīodo de incubacão e viabilidade de ovos de H. virescens, criada em duas dietas artificiais. Temperatura de $24 \pm$ $6^{\circ} \mathrm{C}$, UR de $70 \pm 10 \%$ e fotofase de 14 horas. 
70 .

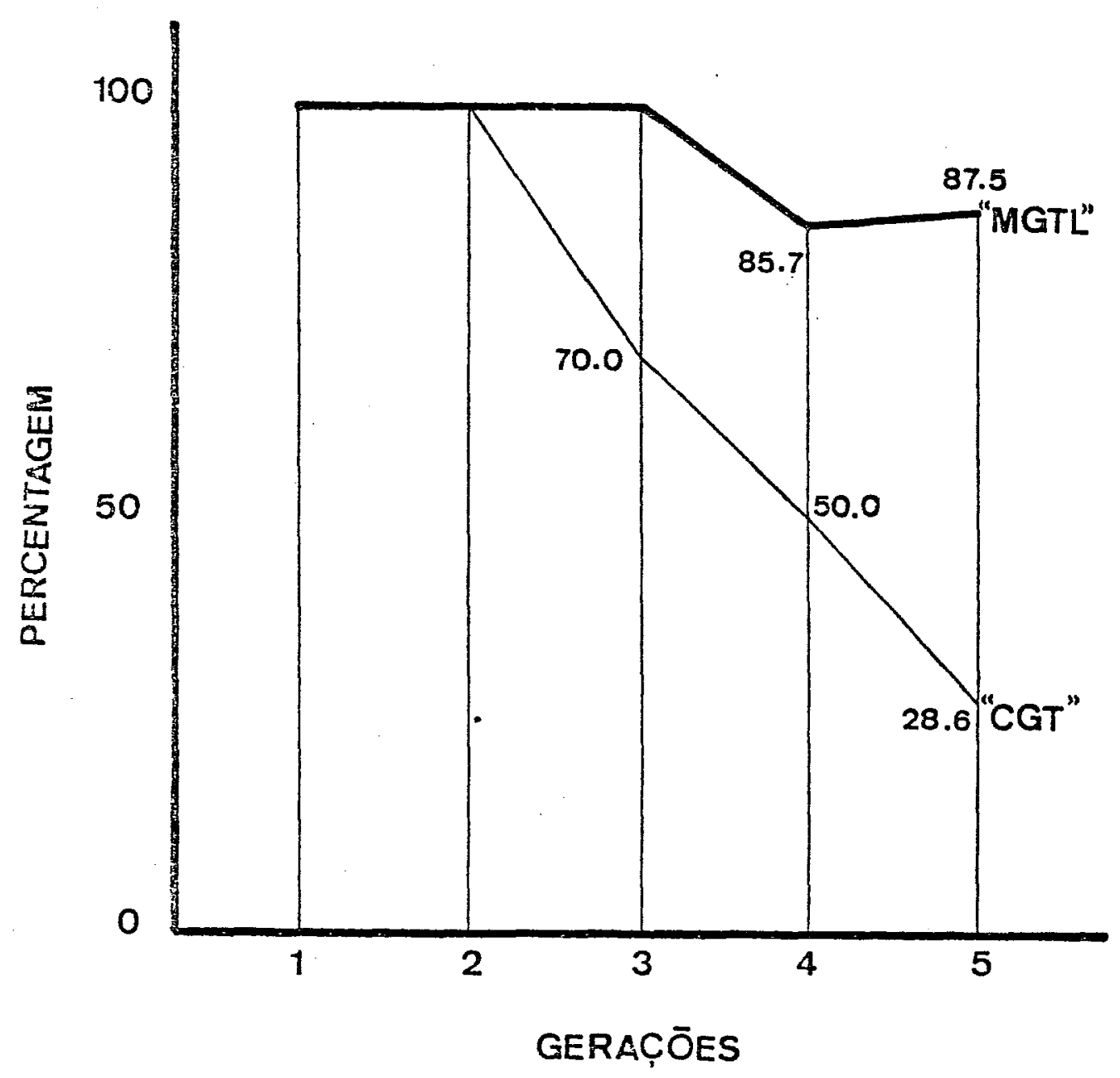

FIGURA 4. Percentual de fëmeas de H. virescens provenientes de duas dietas artificiais, que realizaram posturas em cinco geracões sucessivas. Temperatura de $24 \pm 6{ }^{\circ} \mathrm{C}$, UR de $70 \pm 10 \%$ e fotofase de 14. horas. 
71.

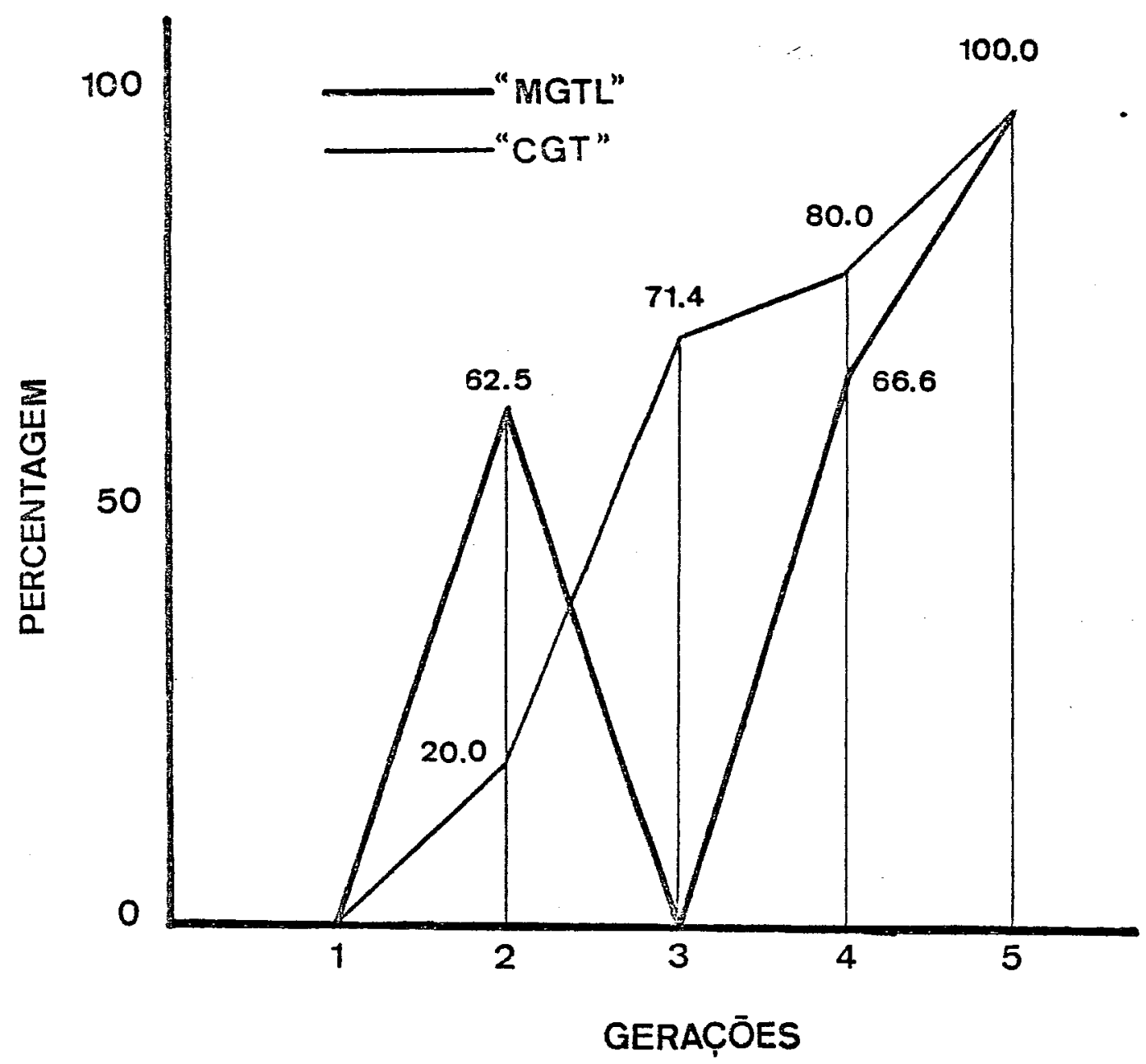

FIGURA 5. Percentual de fëmeas de H. virescens provenientes de duas dietas artificiais, que realizaram posturas inviáveis em cinco gerações sucessivas. Temperatura de $24 \pm 6{ }^{\circ} \mathrm{C}$, UR de $70 \pm 10 \%$ e fotofase de 14 horas. 
TABELA 1. Composição de dietas artificiais, utilizadas para criacão de H. virescens

\begin{tabular}{lcccc}
\hline Ingredientes & $\begin{array}{c}\text { SHAVER e } \\
\text { RAULSTON } \\
(1971)\end{array}$ & $\begin{array}{c}\text { BOWL ING } \\
(1967)\end{array}$ & $\begin{array}{c}\text { POITOUT } \\
\text { e BUES } \\
(1970) \\
\text { (Modificada) }\end{array}$ & $\begin{array}{c}\text { BERGER } \\
\text { (1963) } \\
\text { (Modificada) }\end{array}$ \\
\hline
\end{tabular}

LIQUIDOS (ml)

Acido Acētico (25\%)

Ácido Acëtico Glacial

Agua

Cloreto de Colina (10\%)

Formal de ${ }^{\top}$ do $(10 \%)$

Formaldeido $(37.2 \%)$

Solução Vitaminica (A)

$\mathrm{KOH}(4 \mathrm{~m})$

$\begin{array}{cccc}40.00 & - & - & - \\ - & - & - & 0.13 \\ 3000.00 & 6.400 .00 & 200.00 & 800.00 \\ 25.00 & - & - & 1.00 \\ 15.00 & - & - & - \\ - & 20.00 & - & 0.50 \\ 12.00 & - & - & 10.00 \\ 18.00 & - & - & 5.00\end{array}$

SŌLIDOS $(g)$

Ācido Ascōrbico

Ácido Benzóico

Ácido Sörbico

Ägar

Aureomicina

Caseina

Celulose (B)

Farinha de Mitho (C)

Farinha de Soja

Feijão Cozido (D)

Germe de Trigo

Levedura

Metil P-Hidroxibenzoato

(Nipagin)

Sabugo de Milho (E)

Sacarose

Sais de. Wesson

$\begin{array}{cccc}- & 32.00 & 1.00 & 4.00 \\ - & - & 0.25 & - \\ 3.25 & 10.00 & - & - \\ 15.00 & 128.00 & 5.00 & 25.00 \\ 0.50 & - & - & 0.30 \\ - & - & - & 35.00 \\ - & - & - & 5.00 \\ - & - & 28.00 & - \\ 242.00 & - & - & - \\ - & 2.135 .00 & - & - \\ 108.00 & - & 7.00 & 30.00 \\ - & 320.00 & 7.50 & - \\ 5.40 & 20.00 & 0.20 & 1.50\end{array}$

250.00

44.00

36.00

$\begin{array}{ll}- & - \\ - & -\end{array}$

35.00

10.00

A. Composição da Sol. vitamînica (PARRA, 1979): niacinamida, $110 \mathrm{~g}$; pan totenato de cālcio, $1.0 \mathrm{~g}$; tiamina, $0.5 \mathrm{~g}$; piridoxina, $0.25 \mathrm{~g}$; àci= do fōico, $0.1 \mathrm{~g}$; biotina, $0.02 \mathrm{~g}$; vitamina B12 (1000 mg/cc), 2.0 $\mathrm{m} \ell$; àgua destilada, $1000 \mathrm{~m} \ell$.

B. Läminas de Eucalyptus sp., sulfato branqueados, trituradas em liqui dificador.

C. Milho, variedade VD.2 br $2 \mathrm{O}_{2}$, moido em macromoinho TE-0340 (TECNAL) e peneirado em malha 30 .

D. Feijão da variedade "ROSINHA".

E. Sabugo de milho moìdo em macromoinho TE-0340 (TECNAL). 
TABELA 2. Duração da fase larval (lagarta + pré-pupa) de H. virescens mantida em dietas artificiais à base de farinha de soja - germe de trigo ("SGT"), feijão levedura de cerveja ("FL"), farinha de milho-ger me de trigo - levedura ("MGTL") e caseina-germe de trigo ("CGT"), por geracões sucessivas. Temperatu ra de $24 \pm 6^{\circ} \mathrm{C}$, UR de $70 \pm 10 \%$ e fotofase de 14 horas

\begin{tabular}{|c|c|c|c|c|c|}
\hline \multirow{3}{*}{$\begin{array}{l}\text { Dietas } \\
\text { "SGT" }\end{array}$} & \multirow{3}{*}{$\begin{array}{c}\text { Geracões } \\
F_{1} \\
F_{2} \\
F_{3}^{3} \\
F_{4}^{4} \\
F_{5}\end{array}$} & \multicolumn{4}{|c|}{ Período larval (dias) } \\
\hline & & \multicolumn{2}{|c|}{ Mëdias $\pm s^{*}$} & \multicolumn{2}{|c|}{ I. V. ** } \\
\hline & & $\begin{array}{c}45.46 \\
- \\
- \\
- \\
- \\
45.46\end{array}$ & $\begin{array}{c} \pm 3.45 \\
\pm \quad 3.45\end{array}$ & $44^{\circ}$ & $\begin{array}{l}-48 \\
- \\
- \\
- \\
- \\
-\end{array}$ \\
\hline \multirow[t]{2}{*}{ "FL" } & $\begin{array}{l}F_{1} \\
F_{2} \\
F_{3} \\
F_{4} \\
F_{5}\end{array}$ & $\begin{array}{c}50.39 \\
50.50 \\
- \\
- \\
-\end{array}$ & $\begin{array}{l} \pm 8.90 \\
\pm 15.01\end{array}$ & $\begin{array}{l}30 \\
33\end{array}$ & $\begin{array}{l}-77 \\
-\quad 75 \\
- \\
-\end{array}$ \\
\hline & Total & 50.45 & \pm 11.96 & 30 & -77 \\
\hline \multirow[t]{2}{*}{ "MGTL" } & $\begin{array}{l}F_{1} \\
F_{2} \\
F_{3} \\
F_{5}\end{array}$ & $\begin{array}{l}20.09 \\
19.37 \\
19.29 \\
19.24 \\
17.34\end{array}$ & $\begin{array}{l} \pm \quad 3.95 \\
\pm \quad 2.50 \\
\pm \quad 2.33 \\
\pm \quad 2.60 \\
\pm \quad 1.98\end{array}$ & $\begin{array}{l}17 \\
15 \\
16 \\
1.5 \\
15\end{array}$ & $\begin{array}{l}-25 \\
-\quad 28 \\
-\quad 28 \\
-28 \\
-28\end{array}$ \\
\hline & Total & 19.05 & \pm 2.67 & 15 & -28 \\
\hline \multirow[t]{2}{*}{ "CGT" } & $\begin{array}{l}F_{1} \\
F_{2} \\
F_{3} \\
F_{4} \\
F_{5}\end{array}$ & $\begin{array}{l}23.30 \\
32.51 \\
26.00 \\
26.58 \\
31.96\end{array}$ & $\begin{array}{l} \pm \quad 5.13 \\
\pm \quad 3.80 \\
\pm \quad 3.55 \\
\pm \quad 4.25 \\
\pm \quad 4.48\end{array}$ & $\begin{array}{l}18 \\
20 \\
19 \\
18 \\
24\end{array}$ & $\begin{array}{l}-43 \\
-\quad 45 \\
-46 \\
-46 \\
-\quad 50\end{array}$ \\
\hline & Total & 28.07 & \pm 4.24 & 18 & -50 \\
\hline
\end{tabular}

Erro padrão.

** Intervalo de variacão. 


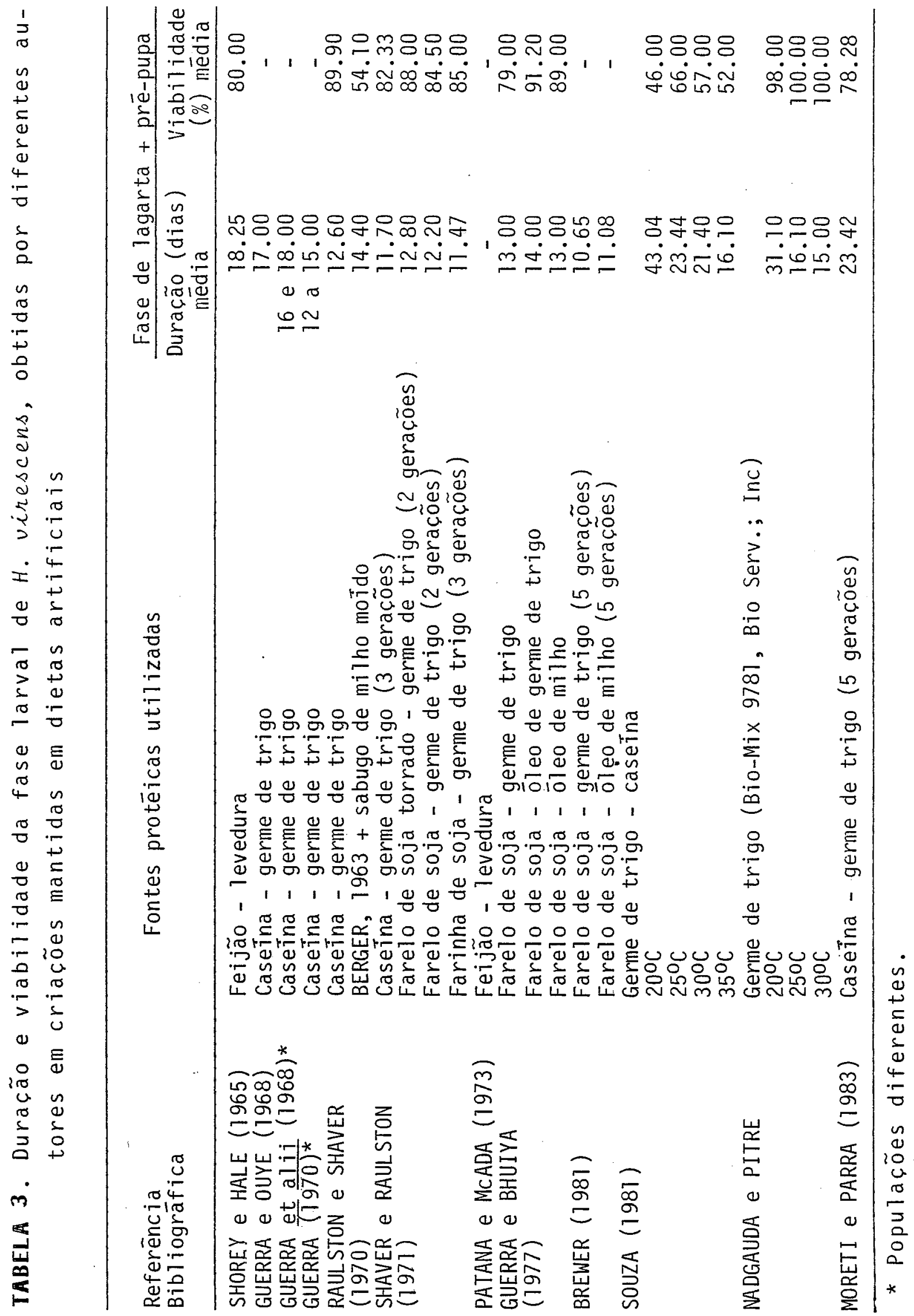




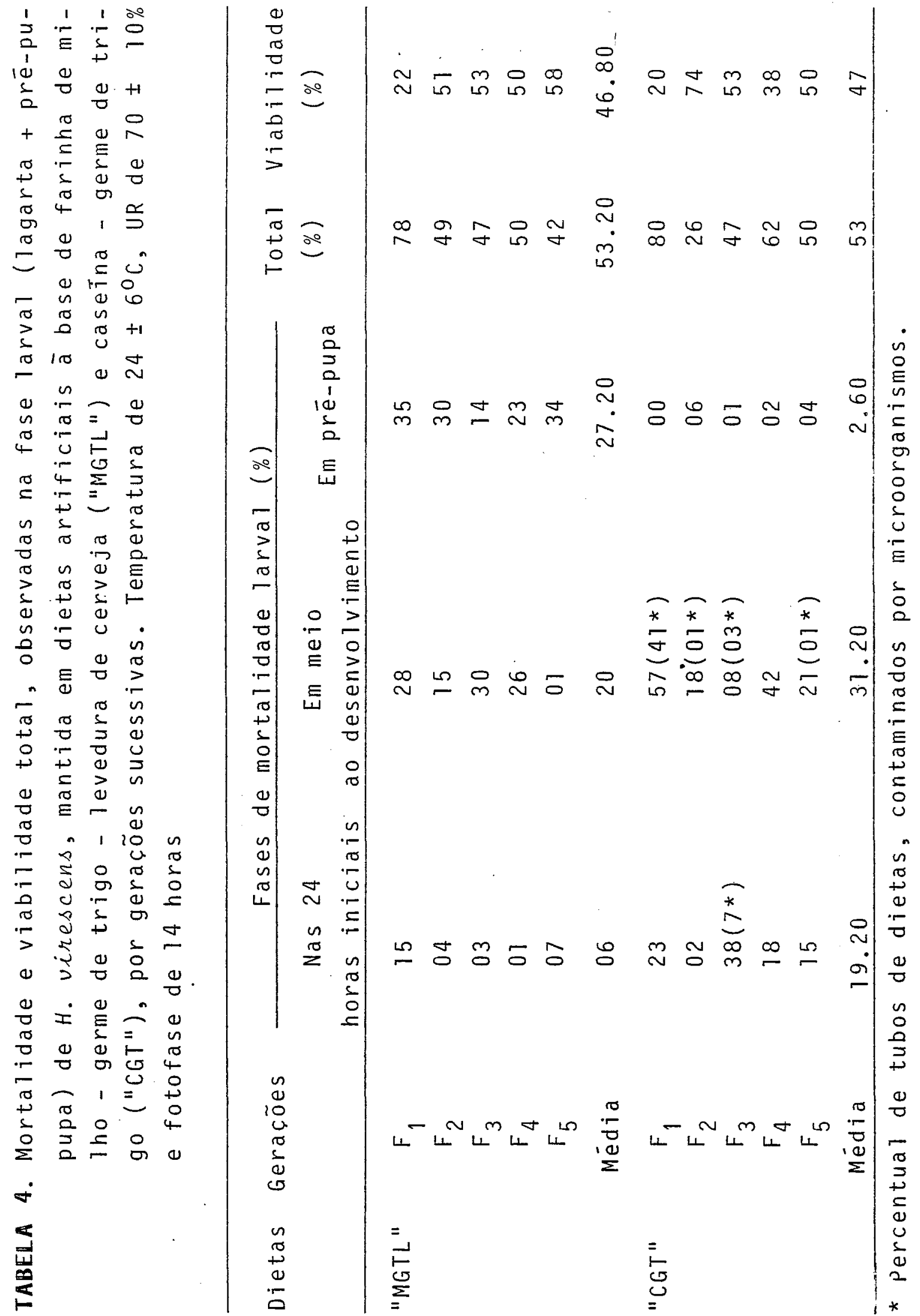


TABELA 5. Duraçăo da fase, proporção e razão sexual de pupas de H. virescens, provenientes de lagartas mantidas em dietas artificiais, à base de farinha de mitho germe de trigo - levedura de cerveja ("MGTL") e caseina - germe de trigo ("CGT"), por geraçöes sucessivas. Temperatura de $24 \pm 6{ }^{\circ} \mathrm{C}$, UR de $70 \pm 10 \%$ e fo tofase de 14 horas

\begin{tabular}{|c|c|c|c|c|c|c|}
\hline \multirow[t]{2}{*}{ Dietas } & \multirow[t]{2}{*}{ Gerações } & \multicolumn{3}{|c|}{ Perriodo pupal (dias) } & \multirow{2}{*}{$\begin{array}{c}\text { P. sexual } \\
0^{\circ}: \stackrel{o}{ }\end{array}$} & \multirow{2}{*}{$\begin{array}{l}\text { Razão } \\
\text { sexual }\end{array}$} \\
\hline & & Média & $\pm \pm s^{*}$ & I.V.** & & \\
\hline \multirow[t]{6}{*}{ "MGTL" } & $F_{1}$ & 16.23 & \pm 4.01 & $14-19$ & $1: 1$ & 0.50 \\
\hline & $\mathrm{F}_{2}$ & 15.57 & \pm 2.26 & $13-19$ & $1: 0.96$ & 0.49 \\
\hline & $\mathrm{F}_{3}$ & 13.93 & \pm 1.80 & $11-17$ & $1: 1.24$ & 0.55 \\
\hline & $\mathrm{F}_{4}$ & 13.80 & \pm 1.94 & $09-15$ & $1: 0.81$ & 0.45 \\
\hline & $F_{5}$ & 14.40 & \pm 2.04 & $13-16$ & $1: 0.93$ & 0.48 \\
\hline & Total. & 14.79 & \pm 2.41 & $09-19$ & $1: 0.99$ & 0.49 \\
\hline \multirow[t]{6}{*}{ "CGT" } & $F_{1}$ & 16.06 & \pm 3.52 & $14-19$ & $1: 1.5$ & 0.60 \\
\hline & $\mathrm{F}_{2}$ & 14.17 & \pm 4.40 & $12-17$ & $1: 0.74$ & 0.42 \\
\hline & $\mathrm{F}_{3}$ & 13.88 & \pm 1.97 & $12-17$ & $1: 1$ & 0.50 \\
\hline & $\mathrm{F}_{4}$ & 14.39 & \pm 2.27 & $12-16$ & $1: 0.73$ & 0.42 \\
\hline & $\mathrm{F}_{5}$ & 15.17 & \pm 2.43 & $13-21$ & $1: 0.72$ & 0.4 .2 \\
\hline & Total & 14.73 & \pm 2.89 & $12-19$ & $1: 0.94$ & 0.47 \\
\hline
\end{tabular}

* Erro padrão.

* Intervalo de variacão. 


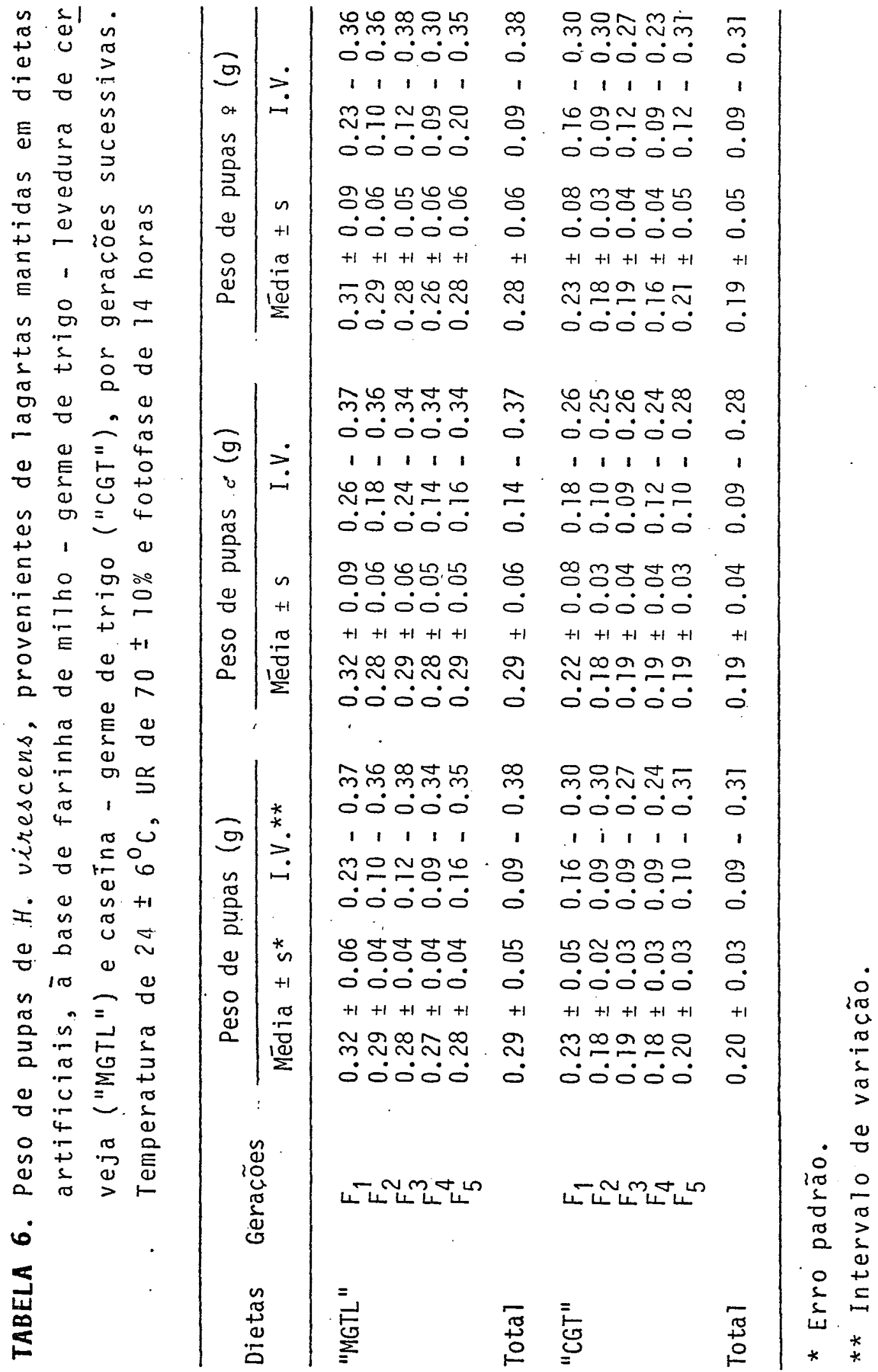




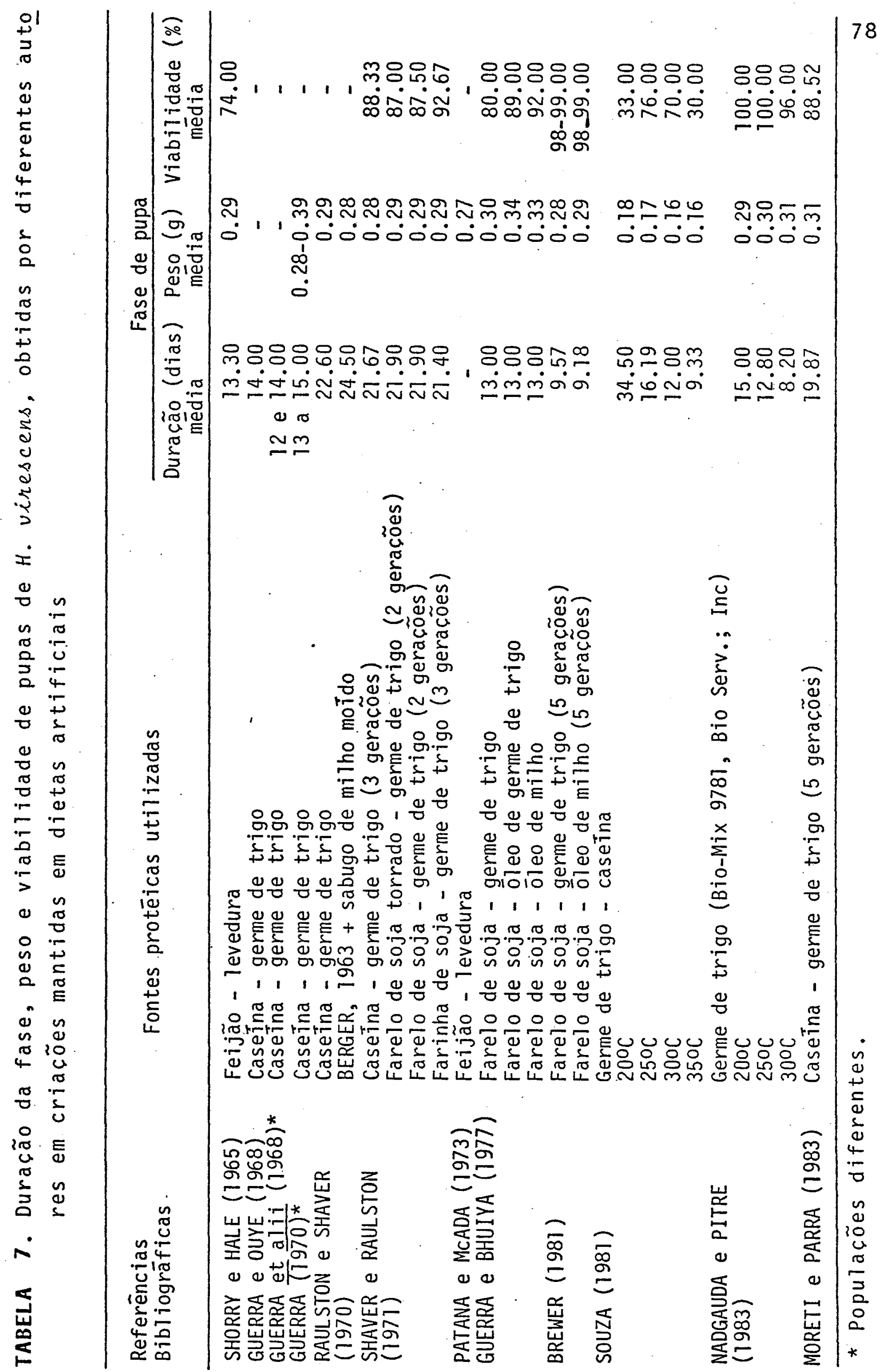




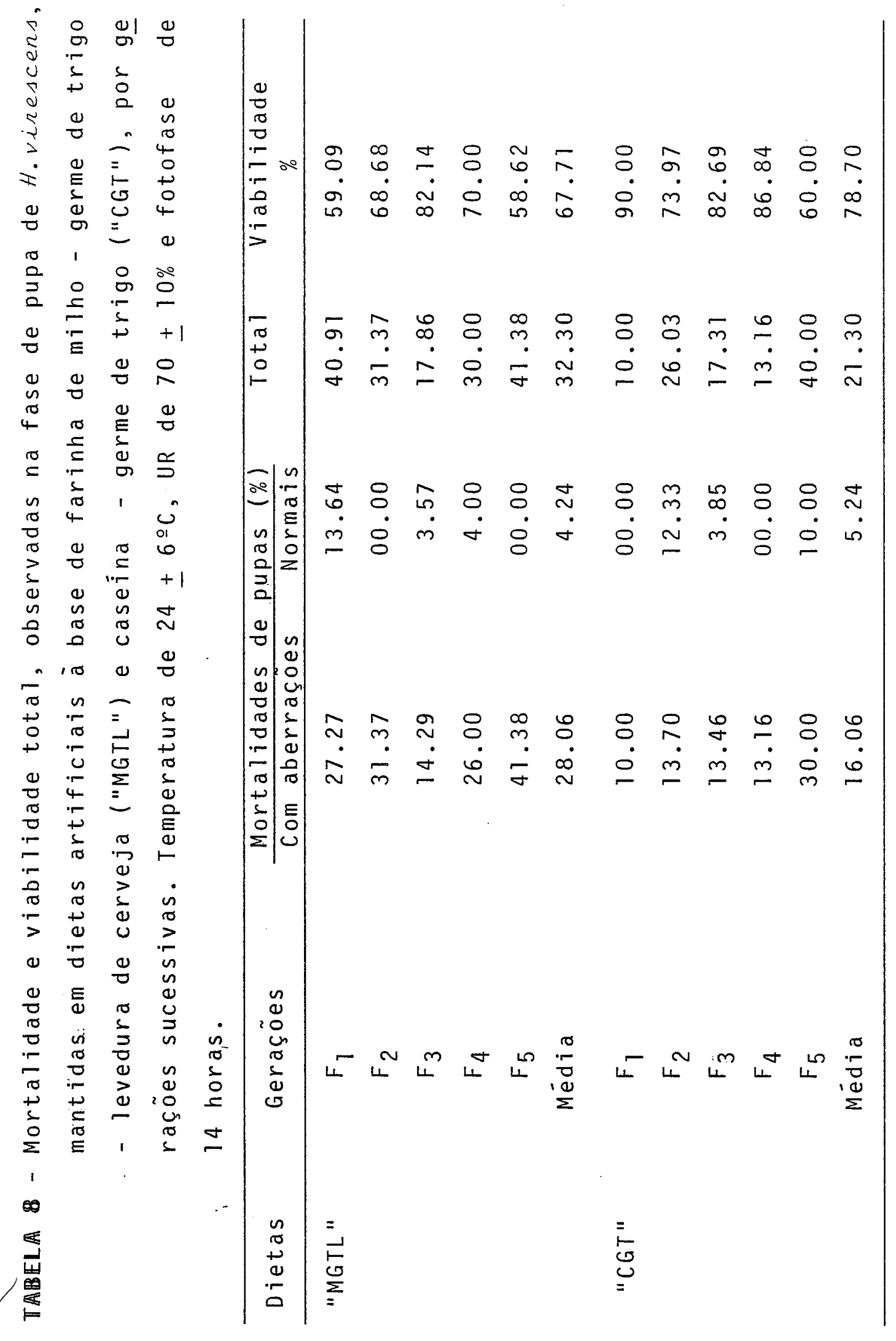


80.

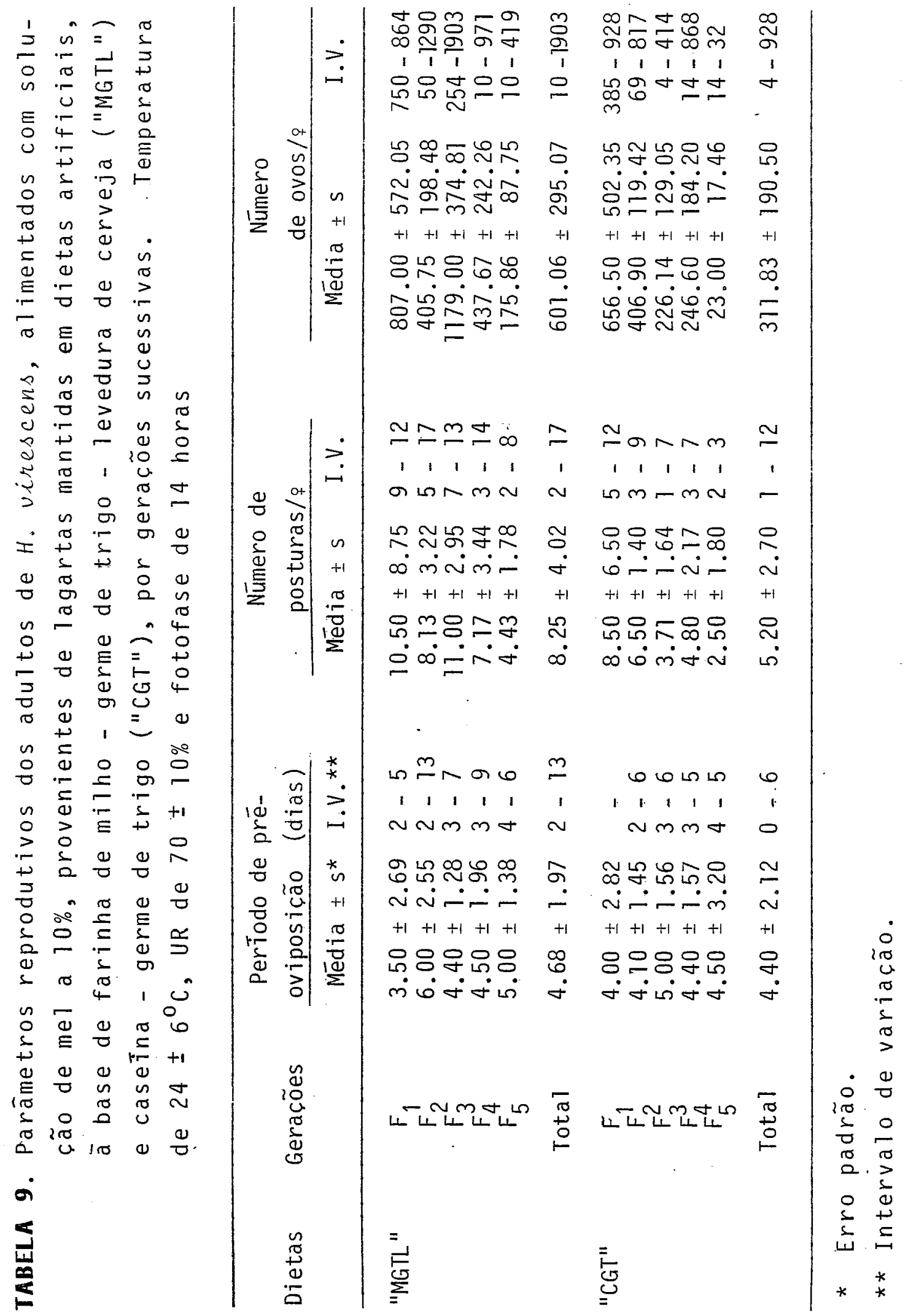




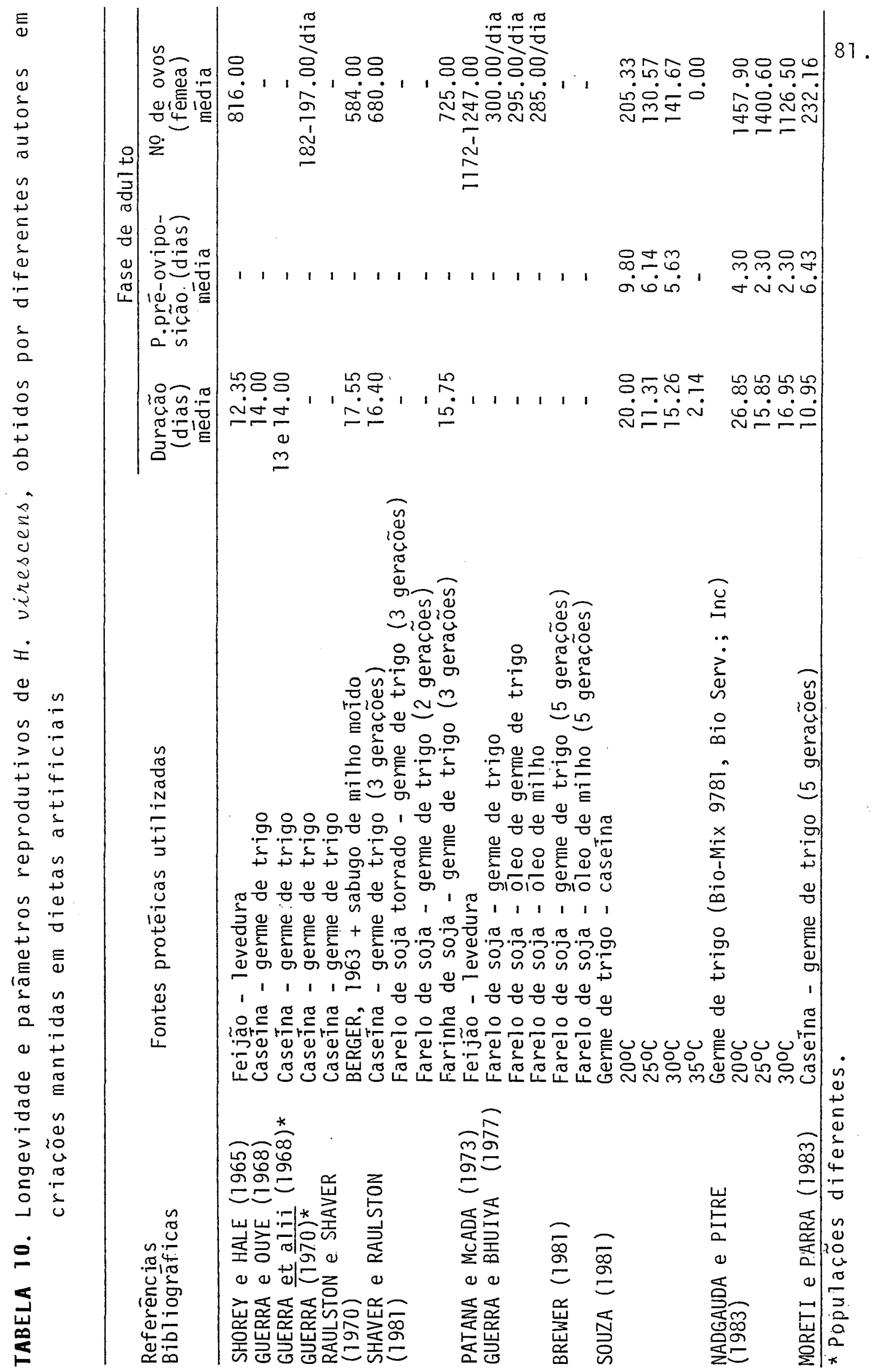


TABELA 11. Longevidade dos adultos de H. virescens, alimentados com solução de mel a $10 \%$, provenientes de lagartas mantidas em dietas artificiais, à basede farinha de milho - germe de trigo - levedura de cerveja ("MGTL") e caseina-germe detrigo. ("CGT") por gerações sucessivas. Temperatura de $24 \pm 6^{\circ} \mathrm{C}$, UR de $70 \pm 10 \%$ e fotofase de 14 horas

\begin{tabular}{|c|c|c|c|c|c|c|c|c|}
\hline \multirow[t]{2}{*}{ Dietas } & \multirow[t]{2}{*}{ Gerações } & \multicolumn{3}{|c|}{$\begin{array}{c}\text { Longevidade do }{ }^{*} \\
\text { (dias) }\end{array}$} & \multicolumn{4}{|c|}{$\begin{array}{c}\text { Longevidade da o } \\
\text { (dias) }\end{array}$} \\
\hline & & Mëdià & $\pm s^{*}$ & I. V..$* *$ & Média & \pm & $\pm s^{*}$ & I.V.** \\
\hline \multirow[t]{5}{*}{ "MGTL" } & $F_{1}$ & 17.00 & \pm 12.21 & $14-20$ & 15.00 & \pm & 11.01 & $14-17$ \\
\hline & $F_{2}$ & 17.88 & $\pm \quad 6.35$ & $11-24$ & 15.63 & \pm & 5.73 & $5-21$ \\
\hline & $\mathrm{F}_{3}$ & 19.40 & 5.28 & $16-26$ & 15.30 & \pm & 4.18 & $12-20$ \\
\hline & $\mathrm{F}_{4}$ & 15.71 & \pm 6.02 & $7-23$ & 13.00 & \pm & 4.94 & $8-17$ \\
\hline & $\mathrm{F}_{5}$ & 16.13 & $\pm \quad 6.00$ & $9-26$ & 12.50 & \pm & 4.29 & $7-17$ \\
\hline Total & & 17.22 & \pm 7.17 & $7-26$ & 14.39 & \pm & 6.03 & $5-21$ \\
\hline \multirow[t]{5}{*}{ "CGT" } & $F_{1}$ & 14.50 & \pm 10.26 & $14-15$ & 12.00 & \pm & 8.94 & $8-16$ \\
\hline & $F_{2}$ & 11.00 & \pm 2.73 & $4-15$ & 11.30 & \pm & 3.08 & $5-15$ \\
\hline & $F_{3}$ & 10.10 & \pm 4.08 & $6-16$ & 9.60 & \pm & 3.10 & $5-19$ \\
\hline & $\mathrm{F}_{4}$ & 8.40 & \pm 2.38 & $7-11$ & 8.90 & \pm & 2.61 & $7-12$ \\
\hline & $\mathrm{F}_{5}$ & 10.14 & \pm 4.39 & $8-12$ & 9.86 & \pm & 3.61 & $8-11$ \\
\hline Tota 1 & & 10.83 & $\pm \quad 4.77$ & $4-15$ & 10.33 & \pm & 4.27 & $5-19$ \\
\hline
\end{tabular}

* Erro padrão.

** Intervalo de variação. 
83.

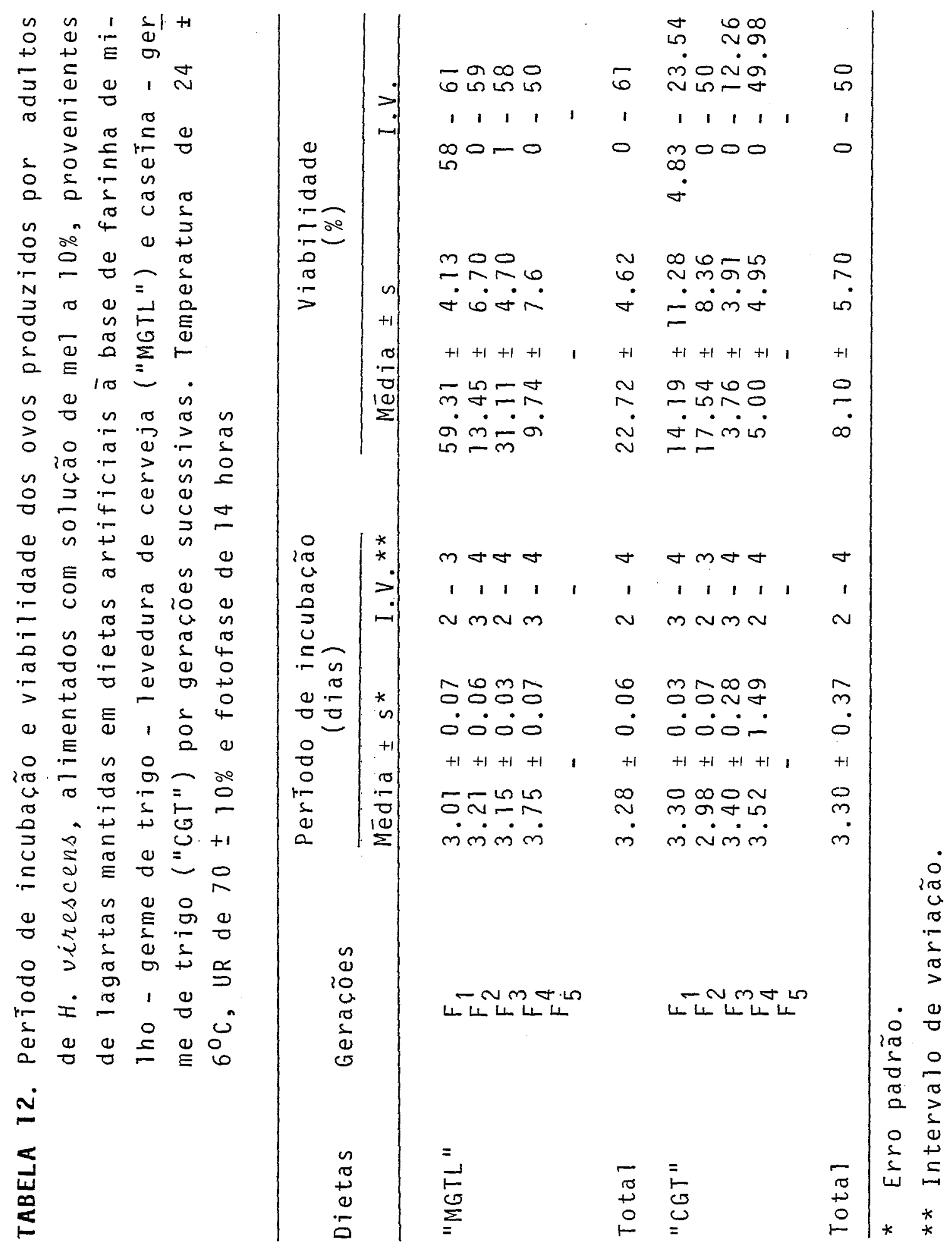


84.

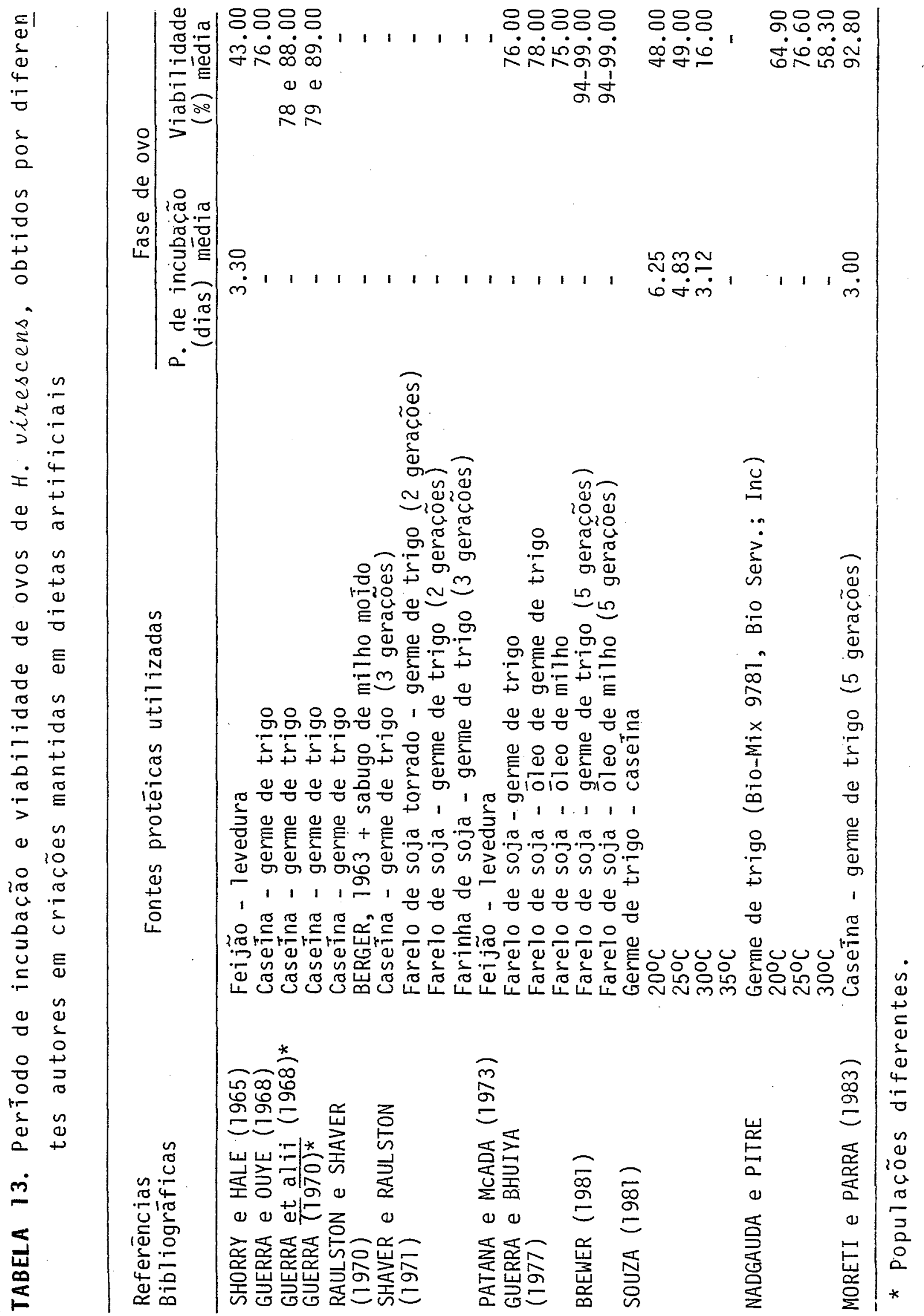


TABELA 14. Consumo e utilização de alimentos por lagartas de H. virescens, no máximo desenvolvimento da ge raçăo $F_{2}$, mantidas em dietas artificiais à base de farinha de milho - germe de trigo - levedura de cerveja ("MGTL") e caseina - germe de trigo ("CGT"). Temperatura de $24 \pm 6{ }^{\circ} \mathrm{C}$, UR de $70 \pm 10 \%$ e fotofase de 14 horas

Parāmetros nutricionais Peso seco $(g)$

Dietas artificiais

\begin{tabular}{cc}
\hline "MGTL" & "CGT" \\
Mēdia $\pm s^{*}$ & Mēdia $\pm s$ \\
$0.55 \pm 0.10$ & $0.38 \pm 0.04$ \\
$0.34 \pm 0.06$ & $0.19 \pm 0.04$ \\
$0.21 \pm 0.04$ & $0.19 \pm 0.04$ \\
$0.12 \pm 0.02$ & $0.07 \pm 0.02$ \\
\end{tabular}

* Erro padrão. 
TABELA 15. Indices nutricionais alcançados por lagartas de H. virescens, no māximo desenvolvimento da geracão $F_{2}$, mantidas em dietas artificiais à base de farinha de milho - germe de trigo - levedura de cerveja ("MGTL") e caseina - germe de trigo ("CGT"). Temperatura de $24 \pm 6{ }^{\circ} \mathrm{C}$, UR de $70 \pm 10 \%$ e fotofase de 14 horas

Indices nutricionais (\%)

Dietas artificiais

\begin{tabular}{|c|c|c|}
\hline$(\%)$ & "MGTL" & "CGT" \\
\hline & Mëdià $\pm s$ * & Mëdia $\pm s$ \\
\hline ECI & $21.72 \pm 4.51$ & $18.49 \pm 3.86$ \\
\hline$A D$ & $38.68 \pm 6.97$ & $50.19 \pm 10.36$ \\
\hline ECD & $56.15 \pm 10.34$ & $36.83 \pm 7.54$ \\
\hline $\begin{array}{l}\text { Custo metabólico } \\
(100-E C D)\end{array}$ & $43.85 \pm 7.97$ & $63.17 \pm 12.87$ \\
\hline
\end{tabular}

* Erro padrão. 